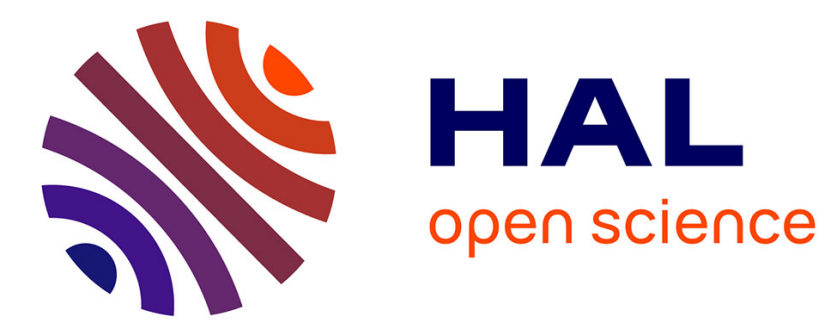

\title{
Does Work Pay in France? Monetary Incentives, Hours Constraints and the Guaranteed Minimum Income
}

\author{
Marc Gurgand, David Margolis
}

\section{To cite this version:}

Marc Gurgand, David Margolis. Does Work Pay in France? Monetary Incentives, Hours Constraints and the Guaranteed Minimum Income. Journal of Public Economics, 2008, 92 (7), pp.1669-1697. 10.1016/j.jpubeco.2007.10.008 . halshs-00202299

\section{HAL Id: halshs-00202299 \\ https://shs.hal.science/halshs-00202299}

Submitted on 4 Jan 2008

HAL is a multi-disciplinary open access archive for the deposit and dissemination of scientific research documents, whether they are published or not. The documents may come from teaching and research institutions in France or abroad, or from public or private research centers.
L'archive ouverte pluridisciplinaire HAL, est destinée au dépôt et à la diffusion de documents scientifiques de niveau recherche, publiés ou non, émanant des établissements d'enseignement et de recherche français ou étrangers, des laboratoires publics ou privés. 


\title{
Does Work Pay in France? Monetary Incentives, Hours Constraints and the Guaranteed Minimum Income
}

\author{
Marc Gurgand*and David N. Margolis ${ }^{\dagger}$
}

September 2007

\begin{abstract}
This paper uses a representative sample of individuals on France's main welfare program (the Revenu Minimum d'Insertion, or RMI) to estimate monetary incentives for employment among welfare recipients. Based on the estimated joint distribution of wages and hours potentially offered to each individual, we compute potential gains from working in a very detailed manner. Relating these gains to observed employment, we then estimate a simple structural labor supply model. We find that potential gains are almost always positive but very small on average, especially for single mothers, because of the high implicit marginal tax rates embedded in the system. Employment rates are sensitive to incentives with extensive margin elasticities for both men and women usually below one. Conditional on these elasticities, simulations indicate that existing policies devoted to reducing marginal tax rates at the bottom of the income distribution, such as the interressement earnings top-up program, have little impact in this population due to their very limited scope. The recently introduced negative income tax (Prime pour l'emploi), seems to be an exception.
\end{abstract}

Keywords: Welfare, labor earnings, transfers, tax-system JEL Codes: I38, J31, C34

\footnotetext{
${ }^{*}$ Paris School of Economics - Paris-Jourdan Sciences Economiques (joint research unit CNRS-ENS-EHESS-ENPC), CREST and IRES.

${ }^{\dagger}$ Université Paris 1, CNRS; Paris School of Economics, CREST; IZA. Mailing address: Centre d'Economie de la Sorbonne, Université Paris 1 Panthéon-Sorbonne, 106-112 boulevard de l'Hôpital, 75647 Paris Cedex 13, France. Telephone: +33 (0)1 440782 62. Fax: +33 (0)1 440782 47. E-mail: David.Margolis@univ-paris1.fr.
} 


\section{Introduction}

Much of the debate surrounding the question of "Making Work Pay" (OECD, 2003) turns on two questions: a) how much additional disposable income would an individual or household gain by moving from welfare to work and b) what is the elasticity of labor supply at the extensive margin with respect to the monetary gain (or loss) in disposable income that a household would experience by shifting from welfare to work. The vast majority of empirical studies have focused on the North American (and the United States in particular) labor markets (Moffitt, 2002), while it seems clear, in a prima facie sense, that an analysis of the policy of a guaranteed minimum income is likely to be more relevant for European countries, as the level and ubiquity of these policies is much more important on the eastern shore of the Atlantic.

This paper provides contributions along these two dimensions while adopting a methodological approach that treats job offers as wage-hours pairs rather than simple wage offers for which the individual can choose hours freely. This approach has been adopted by many authors in the past ${ }^{1}$ and seems particularly appropriate when modeling labor supply in France, the country upon which the empirical analysis in this paper is based. In particular, the empirical distribution of hours worked tends to be bimodal (including for men in our sample) largely as a result of the numerous institutional constraints that concern weekly hours.

In this context, we provide a model of labor supply in the presence of individual-specific wage-hours job offers that we take to data on a representative sample of welfare recipients in France in December 1996. We focus on recipients of France's guaranteed minimum income program (the Revenu Minimum d'Insertion, or RMI) which is central in the country's welfare policies: more than 1 million households receive payments from the $R M I$ system, covering approximately $3 \%$ of the population. Among welfare beneficiaries, these people are in a position to work (in contrast with the handicapped or the elderly on specific welfare programs), and at the same time face high implicit marginal tax rates. This population is thus a major target for policies aimed at making work pay. It must be acknowledged that, except for low wage workers very close to RMI eligibility, our results either in terms of job offer distributions, implicit taxes on labour earnings or working behavior, may not by extended to a larger population potentially exposed to falling into welfare. Nevertheless, this analysis requires very detailed data in order to compute disposable income in a complex setting and such data is not available for a wide range of the population although it is available for the $R M I$ recipient population covered by the survey we use.

On the whole, we see the contribution of this paper to the literature

\footnotetext{
${ }^{1}$ See, for example, Altonji and Paxson (1988, 1992), Kahn and Lang (1991, 1996), Dickens and Lundberg (1993), Stewart and Swaffield (1997), Euwals and van Soest (1999), Meyer and Rosenbaum (2001) and Laroque and Salanié (2003).
} 
as four-fold. First, we develop a theoretical model in which job offers are individual specific wage and hours combinations that we estimate for welfare recipients in a parametric but very flexible manner, that encompasses many institutional settings and fits the data very closely. Second, through a detailed modeling of France's tax and transfer system, we identify important discontinuities and conditionalities in the function that translates net (of payroll tax) earnings into disposable income and we quantify its impact on work incentives. Third, we estimate a simple structural labor supply model that accommodates many important aspects of France's labor market. Identification of this model relies on exclusion restrictions in the vectors of determinants of the job offer distribution and the utility function (as is typically the case in this literature) and on exploitation of the particularities of France's tax and transfer rules. Finally, we simulate several alternative policy settings, including policies that were implemented in France several years after the data were collected, in order to better evaluate the anticipated labor supply response to different sorts of reforms.

Our estimation of the job offer distribution and our calculations of disposable income in the case of work or welfare suggest that the monetary gain in household income when accepting a typical job offer is positive, but often quite small with half the population of welfare recipients experiencing at most a $21 \%$ increase in disposable income relative to their disposable income on welfare. These small gains to employment seem driven in large part by hours constraints, in that many welfare recipients can not expect to receive a full-time job offer. There is substantial variation in gains to employment across household types, with childless single-person households experiencing the largest gains (median gains of $32 \%$ ) and couples with at least 2 children experiencing much lower gains (median of 11\%). A time-limited earnings top-up program (intéressement) is offered to welfare recipients with the objective of increasing the monetary gain to employment, however we find that the associated increase is only marginal, due to the limited scope of this program.

Our simulation studies suggest that the elasticity of labor supply at the extensive margin is quite comparable to levels found in the United States and French literature on welfare recipients, with estimates for single men ranging from 1.25 to 0.39 and for single women from 1.10 to 0.44 (depending on the specification). In addition, although we find that the main earnings top-up program does not seem to have the ability to induce large changes in labor supply, certain other policy reforms (such as the Prime Pour l'Emploi negative income tax adopted in 2001) may help accelerate the transition into employment among welfare recipients.

Although there are other studies of the effects of welfare receipt on labor supply in France, ${ }^{2}$ perhaps the closest work to ours comes from Laroque

\footnotetext{
${ }^{2}$ See, for example, Gravel et. al. (2004), Gurgand and Margolis (2001), Hagneré et.
} 
and Salanié (2002). They examine the impact of incentives on labor supply considering the whole fiscal system and total French population. Laroque and Salanié (2003) expands upon Laroque and Salanié (2002) by introducing female part-time work and indirectly integrating the wage-hours pairs that we explicitly model, a dimension neglected from their first paper. In this work, we analyse more carefully the welfare population. In particular, they have incomplete information on household income and do not consider the time-limited welfare earnings top-up program (intéressement). Furthermore, neither of the Laroque and Salanié papers explicitly models the main public employment program (Contrat Emploi Solidarité, or CES). This program accounts for one third of all jobs held by welfare recipients a year after their being sampled and imposes very specific rules on wages, hours and payments under the intéressement earnings top-up program.

The structure of the rest of this paper is as follows. In section 2, a brief account of the French welfare system is presented with an emphasis on the RMI. In section 3 we lay out a model and the econometric techniques employed for estimating potential labor market earnings conditional on observable characteristics. Section 4 discusses the results of estimating the job offer distributions, while section 5 describes the distribution of the size of the monetary incentives implied by the estimates in section 4 . Section 6 considers the link between the gains to employment and the observed probability of employment, while section 7 concludes.

\section{Welfare Income in France}

Since some of our identification depends upon exploiting discontinuities and conditionalities in the French tax and transfer system, we begin with a schematic description of the functioning of France's guaranteed minimum income, the Revenu Minimum d'Insertion (RMI). ${ }^{3}$ Call $s_{R M I}$ the guaranteed minimum income threshold and $T(w)$ the net transfers available to a household with labor income $w$. In the absence of any further incentives, the household benefits from the RMI scheme when $w+T(w)<s_{R M I}$, in which case its guaranteed disposable income is set to $s_{R M I}$. Otherwise, its income is $w+T(w)$. As such, the RMI generates a $100 \%$ implicit marginal tax rate on earnings such that household income is below the RMI threshold.

The intéressement earnings top-up program, which is designed to increase work incentives, reduces this rate to $50 \%$ and extends the range of eligible earnings. But this is only temporary and lasts for the first 750 hours worked. ${ }^{4}$ When this entitlement to interessement is exhausted, the household faces the

\footnotetext{
at. (2003) and Hagneré and Trannoy (2001).

${ }^{3}$ Appendix A provides more detail on the welfare system and the elements on which we focus in our income simulations.

${ }^{4}$ The 750 hour limit was relevant in 1998, the period covered by our data. Since then, the time limit has been extended.
} 
$100 \%$ implicit tax rate on earnings below the RMI threshold and the general income tax system for earnings above this level. ${ }^{5}$

Among the housing-based benefits, households who rent their lodging (or own it and are paying interest) are eligible for subsidies that apply differently to the private and public sector housing. ${ }^{6}$ They depend on taxable income at a decreasing marginal rate, which varies with family composition and on the amount of the rent, and are subject to different thresholds based on the zone of habitation. ${ }^{7}$ In the typical situation, when taxable income is zero and the rent is below the threshold, the subsidy covers up to $90 \%$ of the rent. All of these transfers are included in the household resources when calculating eligibility for the RMI.

This complex system gives rise to a characteristic profile for the RMI beneficiaries effective marginal tax rate on labor income. Figure 1 depicts monthly earned labor income versus disposable income for two typical situations using the rules in effect in July 1998. For a single person that does not receive the housing subsidy, the guaranteed income is 325 euros (less than half of earnings from a month long full-time job at the minimum wage). If not entitled to intéressement, earnings are taxed at $100 \%$ up to 325 euros. For earnings beyond this amount, labor income is taxed at a marginal rate of $0 \%$ then $8 \%$ after 450 euros and $17 \%$ starting at earnings of approximately 900 euros. Because RMI recipients are not subject to an income tax, but become so as soon as they leave the program, their marginal tax rate is locally infinity (at 325 euros in the single person example). This decrease in disposable income is even more pronounced for those eligible for a housing subsidy. $^{8}$

\section{Insert Figure 1 Around Here}

The budget set under intéressement is also presented on figure 1 . The marginal rate is reduced to $50 \%$ and RMI eligibility is extended up to earnings of 650 euros. After 750 hours, the budget set drops down to the bottom line. Naturally, under this scheme, the effect of taxation and housing benefit loss after 650 euros is more pronounced under intéressement, as illustrated in the figure. Under intéressement there is much more incentive to take a 650 euros than, say, a 660 euros job. Such a shift of incentives toward lower wages (or, equivalently, part-time work) is a shared feature of negative income tax schedules (Moffitt, 2003; Saez, 2002).

At the other end of the spectrum, consider a couple with 3 children, one

\footnotetext{
${ }^{5}$ This scheme is complicated by several rules that allow the hours counter to be reset to zero when additional transitions to and from employment take place. We do not consider these complications here.

${ }^{6}$ Allocation logement and Aide personalisée au logement.

${ }^{7}$ The taxable income considered is that of the previous year, something that we do not explicitly take into account in the simulations. As we use the current income, or expected income, for the calculation of tax rates, this is equivalent to imposing a form of stationarity in the income process.

${ }^{8}$ This inconsistency has been corrected in recent legislation.
} 
below 3, which receives a housing subsidy (figure 1 again). The program parameters are different due to the additional household members (with an extra bonus for the third child). Incentives are even lower for this family: the $100 \%$ marginal tax rate extends to higher earnings (up to 538 euros) and the discontinuities are stronger as the marginal effective tax rate drops to about $20 \%$ on average until labor income reaches 2150 euros. This extended range of relatively high marginal effective tax rates is due to the importance of means tested family-related transfers for this type of household.

These examples demonstrate how the French welfare system imposes very high effective marginal tax rates on labor income, up to $100 \%$ (and locally infinity) over a large range of labor earnings, largely due to the accumulation of means-tested transfer schemes. ${ }^{9}$ This point has often been noted in the literature (e.g. Laroque and Salanié (1999), among others). In this context, the presence of interressement has the potential to have some impact on incentives and behavior. Although the entire profile of the marginal tax rate is of interest, certain ranges of figure 1 may be more relevant than others for a given household when the jobs proposed by potential employers in the form of wage-hours pairs tend to be disproportionately situated in particular intervals on the labor earnings axis. A key element of this paper is to identify the points that are relevant to the actual beneficiaries of RMI, and compare those potential incomes with their resources on welfare.

\subsection{Realized Outcomes of the RMI Recipient Population}

Before considering potential gains to employment for the RMI recipient population, it is useful to analyze the realized outcomes for those actually employed at a point in time. Of the initial December 1996 sample, one-third are employed a year later, only $10 \%$ of whom are in self-employment. Among those in employment, $33 \%$ are employed under the CES public employment program. As shown in the appendix tables, the status with respect to the labor market is very similar for men and women in this population.

Figures $2 \mathrm{a}$ and $2 \mathrm{~b}$ report observed monthly earnings (wage rate times hours worked, gross of any transfers). They make clear that the earnings of RMI recipients, once reemployed, are low and concentrated around the halftime and full-time minimum wage. The strong bimodal distribution is very unusual for the male population. It is also clear that active labor market policy, in the form of $C E S$ jobs, plays an important role in this phenomenon. This reinforces the justification for the specification described in section 3.2 and appendix B. It also suggests that the gains to employment might be cyclically sensitive as well as dependent on the attitude of policy makers

\footnotetext{
${ }^{9}$ L'Horty and Anne (2002), using a number of case studies, have shown that additional programs independently implemented by local governments, when they exist, tend to increase further the marginal tax rates. Due to the lack of exhaustive data on these local-level programs, they are not considered in this paper.
} 
toward active labor market policy.

Insert Figures 2a and 2B Around Here

\section{The Model Framework}

In order to estimate the size of the differential between labor market earnings and the RMI, and the resulting impacts on labor supply, we need to be able to impute relevant wages and working hours for those individuals who receive the RMI. This implies the estimation of a model for the joint distribution of potential wage and hours combinations that are offered to individuals with a given set of observable characteristics, based on data on the observed earnings of a selected population. The hypothesis that hours are not freely chosen at a given wage rate has been empirically supported by Galtier (1999), although France is not an isolated case among OECD countries along this dimension (see OECD, 1995, chapter 2). Furthermore, the structure of French payroll taxes on low earners (Remy, 2005) encourages firms to offer part-time jobs and penalizes overtime. Indeed, Roux (2005) finds results consistent with the idea that French firms respond to such tax incentives by varying the share and types of part-time jobs they propose. Finally, this approach can also be justified by the importance of certain sorts of employment promotion contracts, notably the CES (Contrat Emploi Solidarité), that specify particular wage-hours combinations.

We make individual draws in the wage-hours distribution (unconditional on observed employment status) to form the distribution of their potential labor incomes and compare it with welfare. We then relate the resulting labor supply incentives to observed employment status, via a simple static behavioral equation.

The huge discontinuities illustrated in figure 1 would generate ill-behaved likelihood functions if earnings and labor supply equations were to be estimated jointly. Indeed, a marginal change in the wage distribution parameters, for instance, can create a discontinuity in the employment probability. Laroque and Salanié (2002) suggest smoothing the disposable income function, but this is not realistic in our context given the large steps produced by intéressement. Furthermore, such smoothing can remove a potential source of non-parametric identification for the the labor supply model. We thus proceed sequentially by first estimating the joint wage-hours distribution and then conditioning the structural labor supply model on these implied gains to employment. As a result, two employment functions are estimated: one in reduced form (as an auxiliary step necessary to control for selectivity in the job offer distribution estimation) and the other in structural form as presented below. 


\subsection{The Basic Model}

Suppose that employers propose jobs characterized by an hourly wage rate $\left(w^{d}\right)$ and a number of monthly hours worked $\left(h^{d}\right)$. Given the diversity of employers and jobs available in the labor market, a large number of $\left(w^{d}, h^{d}\right)$ pairs can be proposed in the economy to a single person. The distribution of proposed wage-hours pairs forms the labor demand set faced by the individual and is conditional upon his or her productive human capital characteristics $(X)$. We assume that demographic characteristics and family status do affect labor supply but do not affect productive capacities, and are thus not included in the vector $X$ that determines labor demand. These additional variables, and possibly some elements of $X$, are grouped into a vector $Z$ that affects preferences.

Utility is defined with respect to disposable income and hours worked as:

$$
U\left(D\left(w h, y_{0}, Z\right), h ; Z, \varepsilon\right)
$$

where $\varepsilon$ captures unobserved characteristics that affect preferences on top of $Z$. $U$ is a classical utility function that depends on disposable income and on hours worked. For identification purposes, we will assume that an individual's education, although it affects the set of job offers that he or she faces, does not directly affect preferences (conditional on $Z$ ). The function $D(\cdot)$ computes disposable income, based on labor earnings $(w h)$, wealth $\left(y_{0}\right)$ and family characteristics relevant to compute taxes and transfers (at most a subset of $Z$ ). When not working, utility is therefore $U\left(D\left(0, y_{0}, Z\right), 0 ; Z, \varepsilon\right)$ and depends only on $y_{0}, Z$ and $\varepsilon$.

We assume that individuals receive job offers from the joint distribution of $\left(w^{d}, h^{d} \mid X\right)$. A person will accept any such offer which provides at least the utility of not working, that is when:

$$
U\left(D\left(w^{d} h^{d}, y_{0}, Z\right), h^{d} ; Z, \varepsilon\right) \geq U\left(D\left(0, y_{0}, Z\right), 0 ; Z, \varepsilon\right)
$$

Even if $\varepsilon$ is independent from $\left(w^{d}, h^{d} \mid X\right)$, the distribution of observed wages and hours is not representative of the distribution of $\left(w^{d}, h^{d} \mid X\right)$ because condition 1 restricts the set of observed values. For instance, if $U_{D}^{\prime}>0$, observed wages may be on average higher than proposed wages. For this reason, selectivity must be accounted for when estimating the distribution of $\left(w^{d}, h^{d} \mid X\right)$. The existence of variables in $Z$, such as family composition, and $y_{0}$, assumed not to affect proposed wages and hours, is sufficient to identify conditional means as in most selectivity models. However, parametric distributional assumptions are also needed to recover the full distribution.

With an estimate of the distribution of $\left(w^{d}, h^{d} \mid X\right)$ we can proceed in two directions. First, we can describe the size of the monetary work incentive 
provided by the legislation to any individual, as measured by the distribution of

$$
D\left(w^{d} h^{d}, y_{0}, Z\right)-D\left(0, y_{0}, Z\right)
$$

where the first term is derived from the distribution of proposed wages and hours. This answers the question: Does work pay?

Such a comparison is also valid in a present value context, provided that utility when working and utility when not working are discounted using a common discount factor, $\rho$. However it ignores the time-limited nature of the intéressement scheme that temporarily reduces implicit marginal tax rates. Call $t_{I}$ the number of periods of interessement available to a given person (due to the maximum 750 hours entitlement), $D_{I}\left(w h, y_{0}, Z\right)$ the disposable income for those periods and $D_{0}\left(w h, y_{0}, Z\right)$ disposable income thereafter. When $t_{I}>0$, we may compare the present value of disposable income computed as

$$
D\left(w h, y_{0}, Z\right)=\sum_{t=0}^{t_{I}-1} \rho^{t} D_{I}\left(w h, y_{0}, Z\right)+\sum_{t=t_{I}}^{\infty} \rho^{t} D_{0}\left(w h, y_{0}, Z\right)
$$

with

$$
D\left(0, y_{0}, Z\right)=\sum_{t=0}^{\infty} \rho^{t} D_{0}\left(0, y_{0}, Z\right) .
$$

Having estimated the distribution of job offers and characterized disposable income and present value measures of disposable income, we return to the relation between disposable income and labor supply. Equation 1 can be treated as a structural labor supply equation that depends on individual preferences and observed or potential earnings. Taking simple a functional form, we assume that a job with $(w, h)$ is accepted when:

$$
\alpha\left[\log D\left(w h, y_{0}, Z\right)-\log D\left(0, y_{0}, Z\right)\right]+\beta k(h)+Z \delta+\varepsilon>0
$$

where $\alpha$ is the coefficient of disposable income in the utility function, $\beta$ reflects the taste for work and $\delta$ captures differences in the preference for work related to demographic characteristics. We assume two alternative functional forms for $k(h)$ in our structural estimation: $k(h)=\log (h)$ and $k(h)=1_{\{h \in \text { Full Time }\}}$. Thus $\beta$ is negative if people dislike work (conditional on income). Explicit derivations and normalizations, as well as the likelihood function implied by such a model, are detailed in appendix B.

The main source of identification of the distribution of job offers comes from the presence of variables in $Z$ that are not in $X$, and conversely the parameters of the utility function in this model are identified by the presence of variables in $X$ that are not in $Z$. As is standard for this literature, we exclude family characteristics from $X$ and education from $Z$. Intuitively, excluding family characteristics from $X$ provides a source of variation in the 
probability of accepting a job that is not related to the determinants of the job offer itself, allowing us to trace the shape of the job offer distribution for a given $X$ vector . Likewise, excluding education from $Z$ provides a source of variation within the set of accepted job offers that is not due exclusively to the observable determinants of preferences across jobs, allowing us to observe changes in employment probabilities for a given $Z$ vector and thus map out preferences. It should be noted that the parameters of the utility function would be (locally) identified even without this latter exclusion restriction due to the conditionalities ${ }^{10}$ and discontinuities in the $D(\bullet, \bullet, \bullet)$ function. Inevitably, the various functional forms that we assume throughout our estimation also contribute to the identification of the various model parameters (especially with respect to the job offer distribution), although we assume as flexible functional forms as possible throughout in order to minimize the risk that specification error will affect our results.

Note also that, given the discrete nature of this model, comparing employed individuals with different earnings would provide no information on preferences (all of them have preferred observed earnings to no earnings). In contrast to usual continuous labor supply models, ${ }^{11}$ identification of preferences in our model thus relies on the comparison between employed and non-employed agents along dimensions that determine the particular job offers they receive, i.e. the elements of the $X$ vector that are not in $Z$.

\subsection{Econometric Specification and Estimation}

There are several important institutional features that need to be accommodated in our empirical modeling of the joint wage-hours distribution. First, the RMI levels are set such that a full-time job paid the hourly minimum wage raises income significantly, relative to being on welfare. Part-time work is therefore a central issue, as it is the potential source of incentive problems. Furthermore, the existence of a minimum wage ${ }^{12}$ generates a mass point in the distribution of hourly wages that must be taken into account. These two considerations imply that flexible distributional assumptions, or semior non-parametric estimators, are warranted. On another hand, inferring the full unconditional distribution from the observed distribution that is conditional on selection into employment is impossible unless the distribution is

\footnotetext{
${ }^{10}$ Examples of such conditionalities include housing allowances that depend on public or private housing sector, home ownership status and geographic zones.

${ }^{11}$ In many continuous labor supply models, hours are supposed to be a choice variable for the individual. Hours variation conditional on wages can thus be used to gather information on preferences. In our setting, hours are not chosen by the individual per se, but rather each person is faced with a take-it-or-leave-it job offer. In this context, as the wage-hours pair is set by the employer, hours variation conditional on wages is not sufficient to infer preferences.

${ }^{12}$ Much research has been devoted to studying the empirical importance of the minimum wage in France. See, for example, CSERC (1999) and Abowd et. al. (2000).
} 
parameterized. As we are interested in characterizing the entire distribution of gains to employment, we use mixtures of normal and logistic distributions so as to mimic observed distributions within a strictly parametric framework. ${ }^{13}$

One key institutional specificity is the prevalence of a widespread public employment program, the Employment Solidarity Contract (Contrat emploi solidarité, or $C E S$ ), that provides half-time jobs at the minimum wage plus a specific top-up income (but no rights to standard intéressement). In our data, roughly one third of all RMI recipients in the sample that are observed later in employment have $C E S$ jobs, which can only be held in the public sector. ${ }^{14}$ Zoyem (1999) shows that this sort of contract is frequently proposed to RMI recipients, and is occasionally incorporated into an individual's "reinsertion contract". ${ }^{15}$ The possibility that a CES job offer, rather than a regular market job offer, may be received is modelled explicitly.

The structure of the wage-hours model consists mainly of four correlated probit equations: one for being offered a CES or not, one for being offered a market job at the minimum wage vs. above, one for being offered a full-time market job vs. part-time and one for selectivity into employment. Conditional on being offered a job above the minimum wage, an equation estimates the shape of the truncated wage distribution above it; conditional of being offered a full-time job, an equation estimates the shape of the hours distribution around the full-time mode; a similar equation is estimated for part-time. Although the four main probit equations are estimated conditional on $X$ (or $X$ and $Z$ for the selection equation), the wage and hours distributions for regular jobs are not treated as individual specific, i.e. conditional on observable characteristics. This constraint, imposed because of a lack of variability in the data, can be interpreted as saying that there is screening at entry into different types of jobs but that the wage and hours distributions are insensitive to individual characteristics given the set of individuals employed in each job type. The details of the econometric specification can be found in appendix B.

Anticipating our estimation results, figures 3a-3b illustrate the performance of this statistical model. The observed distributions of wages and hours are compared with their distributions simulated from this model (conditional on employment) on the employed population. In spite of its very parametric nature, the presence of mixtures and proper accounting for trun-

\footnotetext{
${ }^{13}$ The distributional assumptions were based purely on goodness-of-fit criteria, as we do not wish to impose any a priori beliefs about any underlying distributions in the economy.

${ }^{14}$ Private sector employers can exploit a number of other subsidised employment schemes that may be relevant for RMI recipients; see L'Horty (2006) for a recent survey. Empirically, however, none of these other schemes provide as important a destination for RMI recipients as $C E S$ contracts.

${ }^{15}$ Reinsertion contracts are programs negotiated between the RMI recipient and his or her caseworker, generally intended to help the RMI recipient plan his or her transition from welfare back into work (Zoyem, 1999).
} 
cation appear to generate a remarkably good fit. Moreover, the observed share of employed at the minimum wage is $69.78 \%$ and the estimated share is $69.45 \%$.

Insert Figures $3 a$ and $3 b$ Around here

\section{Job Offer Distribution Estimation Results}

In this section, we provide some basic descriptive analysis concerning the jobs that RMI recipients obtain when they leave the RMI. We then present the results of estimating the proposed wage and hours distributions. The data (the Outcomes for RMI Recipients Survey, or L'Enquête sur le devenir des personnes sorties du RMI) consists of a representative sample of 2,764 RMI recipients surveyed in 1996 and again one year later. The first wave defines the sample while the second wave is used to describe their labor market status. The sample is restricted to individuals 17-55 years old at the second survey date and, in the structural labor supply model, we further restrict the sample to single persons in order to avoid complicated issues of collective labor supply decision making. Single persons comprise two thirds of the sample and more than half of single women on RMI raise children. A detailed presentation of the data set and descriptive statistics are provided in appendix C.

\subsection{Job Offer Estimation Results}

The results of estimating the distribution of job offers, as described in section 3 , are presented in table 1 . The models were estimated separately for men and women. All continuous variables used in the estimation are standardized to be mean 0 and to have a unit standard deviation, implying that the coefficients are interpretable as the effect of a single standard deviation change in the corresponding variables. Our base regressors include a set of indicator variables corresponding to the highest degree obtained (the reference is primary education), a quadratic polynomial in age, an indicator variable for French nationality and another for living in the Paris region. Disposable income on welfare and other demographic characteristics are included only in the selection equation and represent our primary exclusion restrictions. Overall, the explanatory power of the observed variables in our model seems limited, and this is likely related to the fact that we study a relatively homogeneous population, at least in terms of their labor market prospects.

\subsubsection{Selection Into Employment}

As the correlation coefficients between the selection equation and the various other models make clear, selection bias is an issue for men in the CES equa- 
tion $^{16}$ and for women in the minimum wage and working time models. It is clear that the probability of employment increases with education for both sexes, significantly so for technical or professional education (category 4). Having children, especially young children, reduces the chance that a female who was on welfare in 1996 will be employed in January 1998, although this supply-side mechanism does not appear relevant for men. Women in couples and widows are much less likely to be employed than women who have never been married (conditional on age), whereas men in couples are significantly more likely to be observed in employment relative to never-married men. The profile of employment with respect to age is essentially flat for women, whereas the probability of employment decreases with age for men who received RMI benefits in 1996, at least initially.

It is interesting to note that the reduced form coefficients on disposable income from welfare $\left(D\left(0, y_{0}, Z\right)\right)$ are generally positive, and significantly so for women. This implies that additional income provided by the RMI may not reduce the probability of an individual being observed in employment; on the contrary, higher disposable income while on welfare may actually be associated with an increase in subsequent employment among one-time welfare recipients. That said, the model outlined in section 3.1 has no implication for the sign of this effect, because $D\left(0, y_{0}, Z\right)$ is generally correlated with $D\left(w h, y_{0}, Z\right)$ and it is the difference between the two that is relevant for job acceptance.

\subsubsection{CES and Regular Jobs}

Table 1 suggests that $C E S$ jobs are less common in the Paris region than elsewhere in France, and that the probability that a woman draws a CES is concave with respect to her age. The correlation coefficients suggest, especially for men, that the unobserved events that make a person likely to be employed also increase the chances that the job will be a $C E S$. This may suggest "cream-skimming" behavior on behalf of case workers, since the case worker is the main source of information about these jobs for most RMI recipients (Zoyem, 1999).

Considering the wage and working time models, the estimated intercepts of the minimum wage model imply that the probability of drawing a minimum wage job (for men and women) is roughly 0.85 for a person with mean values of all characteristics included in the model. Furthermore, it appears that the probability that a female welfare recipient will draw a minimum wage job decreases initially with her age then increases again later in life. Among both men and women who do not draw a $C E S$ job offer, the most

\footnotetext{
${ }^{16}$ The tendency of the estimated parameter to head toward the upper bound suggests that this correlation coefficient may be poorly identified. However, this appears to be primarily a sampling issue (and not a case of the parameter being fundamentally unidentifiable), since the same parameter for women behaves much more reasonably.
} 
educated workers are significantly less likely to draw a minimum wage job. Education does not, however, seem to be significantly related to the probability of drawing a (non-CES) full-time job for men or women. Full-time jobs are significantly over-represented among women living in the Paris region, however. As figure $2 \mathrm{~b}$ shows that much of the dispersion in male working time is due simply to the nature of the job (CES or non- $C E S)$, it is not surprising to see no significant determinants in the male working time equation.

The remaining correlation coefficients are only significant for women, and these are only significant at the $10 \%$ level. Still, the signs are negative for both men and women on the correlation between the minimum wage and full time employment equations, suggesting that non-CES minimum wage jobs are also more often part-time than full-time. There is also a negative correlation for both men and women between the disturbances of the employment and minimum wage equations, suggesting that those people more likely to be seen in work are also less likely to draw a minimum wage job when they are not offered a $C E S$.

\section{The Gains to Employment}

We use the results presented in table 1 to assign disposable income for each household in the full (representative) sample. To do this, we draw wage rates and working hours from their estimated distributions, unconditional on employment status (this applies to everyone, whether employed or not). ${ }^{17}$ Given each household's simulated labor earnings, we then apply the system of taxes and transfers present in France in 1998 and described in section 2, to obtain a measure of disposable income while employed. We consider 2 alternative scenarios.

1. A baseline scenario: the intéressement top-up is computed for those who are eligible until their eligibility runs out, then the individual is subject to the regular earnings environment (including the RMI minimum income guarantee) forever;

2. A comparison scenario for evaluating the importance of intéressement: the job is held forever but everyone is assumed to have exhausted their intéressement eligibility; ${ }^{18}$

\footnotetext{
${ }^{17}$ We draw 20 unconditional wage-hours pairs per observation (generating 55,280 points) based on the full econometric model in order to obtain a smoother view of the overall distribution.

${ }^{18}$ This scenario excludes intéressement payments for "regular jobs", although it maintains the appropriate legislation in attributing top-up payments to any individual employed on a $C E S$ because they are not subject to exhaustion and these payments are simply part of the $C E S$ scheme.
} 
Under each scenario, we compute the present value of disposable income as explained in section 3.2 (to account for changes of income flows over time due to the intéressement rules) and convert it to a constant monthly flow. ${ }^{19}$ In the case of individuals living in couples, we assume that the spouse/partner provides no additional labor income (modeling the joint labor supply decision is beyond the scope of this paper). This is compared to the monthly flow of disposable income from the RMI (i.e. assuming no one works) in order to calculate the gain to employment. Table 2 describes the distribution of these gains for different household types and under the different scenarios. Figures $4 \mathrm{a}-4 \mathrm{c}$ trace some of the distributions of gains for the baseline scenario (singles only).

Insert Figures $4 a, 4 b$ and $4 c$ Around Here

Our estimates suggest that almost every household gains from work in the baseline case. This is because the $100 \%$ tax rate only applies in a very particular circumstance: the household has exhausted its entitlement to intéressement, it does not get a $C E S$ job and earnings are below those of a half-time minimum wage job (approximately). This combination happens rarely. On the other hand, the value of the estimated monetary gains are small. For comparability between household types, gains are also computed either per adult equivalent or as a percentage increase over welfare income. The highest gains are for single persons without children, and even then the median gain is only 103.70 euros per month, while median gains are only 30 to 70 euros per person for single parents or couples. It should also be noted that the large difference between mean and median gains suggests a very skewed distribution of gains, with a large probability mass at low levels (driven by $C E S$ jobs) and several higher gains that serve to pull the mean upward: this is confirmed by figures 4a-4c. Figure 4c also shows a small mode for men around full-time work. For women, the distribution is multimodal because of the impact of the number of children (compare figures $4 \mathrm{a}$ and $4 \mathrm{~b})$.

The results for women, especially single mothers, are potentially worrisome and are due to a combination of factors. These women are found in the lower tails of the distributions of wage rates and hours and they are subject to high implicit tax rates through the means-testing of family benefits. These small monetary gains would likely result in a net loss to single mothers when child care costs (not measured here) are added in. The French transfer system includes a special program to subsidize child care, while schooling is free starting at age 3. But it is unlikely that this assistance at the margin would be a sufficient complement to the very small estimated potential gains to employment.

\footnotetext{
${ }^{19}$ We apply a monthly discount factor of 0.995 , which is equivalent to an annual interest rate of roughly $6 \%$
} 
Comparing the baseline to the simulation without intéressement, it appears that the contribution of the intéressement scheme to the distribution of gains is very limited. Intéressement mechanically ensures that $13 \%$ additional beneficiaries will have a strictly positive gain from working (increasing the percentage with gains from $86 \%$ to $99 \%$ ), but there is practically no visible difference in the amounts of the gains to employment. One reason is that the $13 \%$ marginal beneficiaries are among the lowest paid, and as such they contribute small gains.

The other reason for the apparently minor impact of the suppression of the interressement scheme is that the amount of additional gains provided by intéressement is limited on average. Recall that, in this simulation, the suppression of intéressement payments does not concern CES jobs, as they are subject to a separate set of rules. ${ }^{20}$ In addition, the changes relative to the baseline case do not apply to observations with household income above twice the RMI threshold (because then eligibility to both RMI and intéressement is lost), while the top-up only corresponds to $50 \%$ of a small amount when wages are small enough to benefit from the intéressement scheme. Finally, since the top-up is only available for a limited amount of time (750 hours of work or less), the present value of the corresponding "wealth" is only marginally affected by the periods during which the top-up is available, even if one applies a high discount factor. Overall, the features of the interessement system, as of 1998, especially its time-limited nature, seem to imply that it may have a very small potential to affect incentives to work despite the relatively large kinks in the disposable income profiles (see figure 1).

\section{The Relation Between Gains to Work and Em- ployment}

The discussion thus far has been centered on the gains to employment for the entire (representative) population of RMI recipients. However, the possible monetary incentive effects on labor supply of the RMI, insofar as they have behavioral consequences, should be visible when comparing the simulated gains of people actually observed in employment with those of people not observed employed. In particular, equation 1 implies that those observed in employment may tend to have larger gains to employment than comparable workers not observed in employment.

\subsection{Gains to Employment and Observed Employment Status}

Figures 5a and 5b each compare three distributions of hours. Unconditional (on employment status) distributions are simulated for the employed and

\footnotetext{
${ }^{20}$ This is the reason why the median values, which are primarily driven by the prevalence of $C E S$ jobs, remain unaffected.
} 
the non-employed populations (dashed lines). Up to taxes and transfers, this describes the ex ante incentives that are faced by each population and depends only on structural differences in terms of observable characteristics. It is clear that the population that was indeed observed employed has access to longer working times. Moreover, the simulated probability that women are offered only the minimum wage is $82 \%$ in the employed population and $87 \%$ among the unemployed; these figures are $81 \%$ and $85 \%$ respectively for men.

Insert Figures $5 a$ and $5 b$ Around Here

Given that people can only choose to accept or reject the jobs that are proposed to them, observed wages and hours among the employed population are again different from jobs offered to that population. This is, strictly speaking, the selection effect, drawn in solid line on the figures. For both men and women, observed hours are more often around full-time, with clearly higher wages: ${ }^{21} 74 \%$ of women do work for the minimum wage (to be compared to the simulated $82 \%$ offered in the same population); the figure is $66 \%$ for men (to be compared with the simulated $81 \%$ ). Both composition and selection effects combine to generate very different pictures of the observed and potential wages. These results are intuitively appealing: they suggest that jobs high in the earnings distribution are more likely accepted.

Table 3 decomposes the corresponding distributions of gains to employment under the baseline scenario. For the employed population, we compare observed gains to gains that would result from the offered (but not necessarily accepted) wage-hours pairs. This is an alternative means of presenting the selection effect described above. We also compare potential gains for the employed and non-employed populations. Although it is clear that a smaller share of individuals among the population actually observed in employment has positive simulated potential gains, ${ }^{22}$ it is also evident that the value of these gains are, on average, larger. This is true for almost all cells in the table. Furthermore, expressed in terms of gains, the selection effect seems very large: accepted jobs provide higher gains than the average potential job. An important point to note is that this occurs because accepted jobs not only involve a higher wage rate but also a longer working time. With more than $80 \%$ of proposed jobs at the minimum wage, working time becomes an important adjustment variable. It seems that welfare beneficiaries are more willing to accept job offers that propose longer hours, which may signify a desire on their part to increase their gains from employment. Alternatively, working more hours may be sought after as a means to leave welfare or at least reduce its stigma (Laroque and Salanié, 2002). Structural estimates

\footnotetext{
${ }^{21}$ The figures draw marginal distributions, but the correlations estimated in table 1 imply that the effect of wages reinforces that of hours, i.e. a lower probability of a minimum wage job is associated with a higher probability of full-time employment.

${ }^{22}$ This is because the entitlement to interessement in the non-employed population tends to be larger, by construction.
} 
will confirm this view.

\subsection{Structural Labor Supply Estimation}

In order to investigate the relation between gains to employment and labor supply in further detail, we estimate by simulated maximum likelihood the structural employment model defined by equations 3 and 4 in appendix B. ${ }^{23}$ To avoid the complexities related to joint labor market decisions, table 4 presents the results of estimating this employment model on single-adult households only ( $70 \%$ of the sample).

Although the model specification is reduced to its basics, our estimation presents some interesting results. As expected from the above discussion, the income and hours variables have a significant influence on employment probability, although their respective impacts ( $\alpha$ and $\beta$ in equation 2$)$ are difficult to distinguish. The coefficient on disposable income is high and precisely estimated in the absence of the hours variable, suggesting that labor supply is quite sensitive to potential gains in disposable income.

When working time is included, however, the estimated $\alpha$ is typically reduced: individuals remain sensitive to disposable income variations when making their labor supply decisions, but it appears that workers look for extra hours as a separate objective. In principle, the two effects (preference for income and preference with respect to working time) can be distinguished. However, the coefficient $\alpha$ is not always significant. Hours alone explain $89 \%$ of the variance in gains for men and $78 \%$ for women, suggesting that collinearity between income and hours may be driving the insignificant income effect when the full-time dummy is included. Nevertheless, we find that these variables are jointly highly significant (recall that the $99 \%$ confidence level for $\chi^{2}(2)$ is 9.21$){ }^{24}$

It is worth noting that both men and women are more likely to accept jobs that offer more hours of work (for a given income), regardless of whether hours are measured as a continuous variable or with a dummy. These results are compatible with estimates obtained by Laroque and Salanié (2003) for the whole French female population, which leads us to believe that our results are not simply an artifact of the limited variation in the hourly wage variable. ${ }^{25}$ In our context, given that we focus on welfare recipients, the stigma-based explanation for preferring additional hours is credible, as may be explanations in which more monthly hours serve as a "stepping stone" out of welfare and into the mainstream labor market.

\footnotetext{
${ }^{23}$ Details of the estimation are provided in appendix B.

${ }^{24}$ When the age variable is not present, there is less collinearity and the results are more precise, but for a priori labor supply considerations we hesitate to put weight on such a specification.

${ }^{25}$ There is much more variation in the wage rate in Laroque and Salanié's (2003) data, implying a more useful second source of identification.
} 
Finally, table 4 indicates that older beneficiaries are less likely to be observed working in 1998. This result is robust and very precisely estimated and may reflect either discouragement on the part of welfare recipients or discrimination on behalf of employers with respect to older workers in general. Women with young children also work less and this effect is also strong: one more child aged below 3 would decrease the probability of a single woman being employed by $90 \%$ on average. As noted above, this is consistent with the idea that the very low gains that single women can expect from employment, coupled with the likely high costs of caring for small children, can render negative the net return to working for a single mother with small children.

The estimates in table 4 can be used to calculate the elasticity of employment with respect to an increase in gross earnings or disposable income. For example, consider a small increase in disposable income of $\theta$ percent ${ }^{26}$ and base earnings of $w h$. Using the approximation $\log (1+\theta)=\theta$, this gives:

$$
\begin{aligned}
e\left(w h ; y_{0}, Z\right) & =\frac{d P(E m p)}{d D} \times \frac{D}{P(E m p)} \\
\approx & \frac{1}{\theta} \quad\left[\frac{P\left(\alpha \theta+\alpha\left[\log D\left(w h, y_{0}, Z\right)-\log D\left(0, y_{0}, Z\right)\right]+\beta k(h)+Z \delta+\varepsilon>0\right)}{P\left(\alpha\left[\log D\left(w h, y_{0}, Z\right)-\log D\left(0, y_{0}, Z\right)\right]+\beta k(h)+Z \delta+\varepsilon>0\right)}-1\right]
\end{aligned}
$$

The elasticity parameter that we exploit integrates this expression over the set of available job offers for each individual in a population with given characteristics, namely:

$$
e\left(y_{0}, Z\right)=\int_{w} \int_{h} e(w h, ; y, Z) d F(w, h \mid X) .
$$

Given that the function $D(\bullet, \bullet, \bullet)$ is highly nonlinear in its first element, we numerically evaluate this double integral with 500 draws from the joint wage-hours job offer distribution specific to each individual. These results are then averaged over the full population or over subgroups defined by a particular subset of $Z$, in particular men versus women.

Table 4 describes our implied elasticities with respect to gross earnings and with respect to disposable income for each of our model specifications. Our estimates with respect to disposable income range from 1.25 to 0.39 for single men and from 1.10 to 0.44 for single women depending on the specification. As would be expected, the elasticity with respect to gross earnings is always lower than the elasticity with respect to disposable income, due to the tax and transfer system. The fact that the gap between the two elasticities is larger in every specification for women than for men reflects the fact that women face higher implicit tax rates since they are more likely to receive the RMI or intéressement payments even when working; i.e. single

\footnotetext{
${ }^{26}$ In practice, we use $\theta=0.01$ when calculating the elasticities given below.
} 
women are more often on the flatter parts of the earnings-disposable income profiles shown in figure 1 than single men. The elasticities are also lower when controlling for hours worked, as our estimates in table 4 suggest an independent role for hours in labor supply decisions (as noted above) that leads the coefficient in the specification without hours to be biased upward.

These figures are within the bounds of estimates of the extensive margin elasticities computed in the United States and France found elsewhere in the literature. For example, Eissa et. al. (2004) survey the literature on labor supply responses of single mothers to tax changes (in particular those associated with the Earned Income Tax Credit, or EITC) during the 1980s and 1990s in the United States. They find almost no response at the intensive margin (hours adjustment for people already working), but they find an elasticity of labor supply at the extensive margin (working or not working) of 0.35 to 1.7. For France, Piketty (1998) finds elasticities ranging from 0.6 to 1 based on a natural experiment, although his sample of women is not limited to welfare recipients. Laroque and Salanié (2003) use a structural model and estimate an elasticity of 0.97 for women in couples but only 0.36 for single women. In all of these cases, our estimates (for single women) are quite comparable to existing estimates in the literature.

It is worth remembering that our present value of income flows are computed using a $6 \%$ annual discount rate. Given the complexities of the system and the possibility of myopia among a population that is somewhat removed from regular labor market activity, welfare recipients may tend to discount future income much more radically than we have previously assumed. To test the implications of such behavior, we re-estimated the labour supply model using higher discount rates for the income variable. This change is neutral when income is constant over time since our specification compares the logs of disposable income. However, when incomes decrease with time (as is the case for people receiving intéressement payments), increasing the discount rate has the obvious effect of scaling up measured gains to work. Although the estimates should not change qualitatively, the estimated elasticities may adjust downward. For instance, we find that the elasticity with respect to disposable income decreases from 0.54 to 0.33 (based on specification (2)) for women but remains unchanged for men (who receive intéressement payments much less often) when we assume a $30 \%$ discount rate.

\subsection{Policy Simulations Based on the Structural Estimation Results}

The structural model estimated in section 6.2 allows us to simulate the expected labor supply impacts of a number of different policy changes. ${ }^{27}$ It should be remembered, however, that our model is based on partial equilib-

\footnotetext{
${ }^{27}$ Labor supply in our simulations is based on specification (2) in table 4 .
} 
rium and thus large-scale policy experiments that could have macroeconomic effects can not reasonably be considered in this context. In particular, in all of these simulations we assume that the above-minimum wage distribution, the full and part time hours distributions, the probability of receiving CES offers, the probability of receiving a minimum wage job offer and the probability of receiving a draw from the full time hours distribution are unaffected by the policy changes that we simulate.

With this in mind, we consider the following alternative scenarios, which we compare to our baseline scenario:

- Without intéressement

- With infinite-duration intéressement

- With the Prime pour l'emploi (PPE) negative income tax

- With an increase in the minimum wage of $10 \%$

For each of these situations, we consider two outcome measures, the change in the level of employment (relative to the reference scenario) and the public spending implications of the change.

The former effect is evaluated in a straightforward manner (estimating the probability of employment for each individual and taking the average under each scenario), while the latter is more subtle. One can evaluate the monthly value of net transfers made by the government, individual by individual, when an individual works, as $E\left(D\left(w h, y_{0}, Z\right)\right)-E(w h)$ (which can be negative when wh exceeds twice the RMI threshold) while the monthly value of net transfers made by the government when the individual is not employed is $E\left(D\left(0, y_{0}, Z\right)\right)$ (which is always positive). This implies that that one can evaluate the total impact of each scenario on government revenues as: ${ }^{28}$

$$
\begin{aligned}
& \text { NetTransfers }=\sum_{i}\left\{P\left(E m p_{i}\right)\left[E\left(D\left(w_{i} h_{i}, y_{0, i}, Z_{i}\right)\right)-E\left(w_{i} h_{i}\right)\right]\right\} \\
& +\left\{\left[1-P\left(E m p_{i}\right)\right] D\left(0, y_{0, i}, Z_{i}\right)\right\} .
\end{aligned}
$$

We begin by presenting the baseline simulation in table 5 . The baseline scenario presents actual employment rates along with simulated ones using the legislative framework actually in place in 1997 . We simulate both earnings and employment, and table 5 shows that our simulations are very close to the observed employment rates due to the good fit of the model. Under the baseline scenario, net government transfers on average amount to 325 euros per month for single male welfare recipients and 521 euros for single women. The higher transfers to women reflect the fact that single women are more likely to raise children than single men, and child benefits represent a relatively large transfer amount.

\footnotetext{
${ }^{28}$ All probabilities and expectations are taken with respect to the joint distribution of job offers $(w h)$, conditional on observed characteristics.
} 


\subsubsection{No Intéressement Simulation}

In this simulation, we calculate the disposable income from employment as if the individual had exhausted all eligibility for intéressement payments and thus received disposable income from work with no in-work benefits. This gives rise to a tiny decrease in disposable income on average: as noted above, there are relatively few individuals who receive the earnings top-up and, in a present value computation, the few months of interressement payments receive little weight. Therefore, the policy has almost no impact. As table 5 shows, the average monthly flow of in-work disposable income falls by only $0.09 \%$ for men and $0.31 \%$ for women. Eliminating the intéressement system would thus have very little negative impact on labor supply, with male labor supply decreasing by $0.10 \%$ and female labor supply by $0.18 \%$. However, since the payments are so rarely made and represent such a small amount of in-work disposable income, the effect on public finances of eliminating intéressement would be essentially nil.

\subsubsection{Infinite-Duration Intéressement Simulation}

In this simulation we suppose that eligible individuals can receive intéressement in-work benefits, according to the rules described in section 2 and appendix A, indefinitely. Given our method of converting present values to monthly equivalents, this is the same as considering the case of complete myopia for an individual with at least some rights to intéressement, in which the date at which intéressement payments run out is never considered.

As seen in table 5, the average increase in disposable income at work is not high ( $1.50 \%$ for men and $5.80 \%$ for women), both because of the large share of CES contracts and because most full time workers exceed the income threshold that renders them eligible for intéressement payments. The employment impacts of extending intéressement benefits forever would be larger than those of eliminating the program (due to discounting and the time-limited nature of these benefits): female employment increases by $3.2 \%$ and male employment by $1.5 \%$. Such an increase in labor supply comes at the relatively modest cost of one extra euro per month for single men and ten extra euros per month for single women. These two simulations illustrate, however, the small potential for affecting labor supply of a policy instrument that is so strongly limited in scope. 


\subsubsection{Negative Income Tax, or Prime Pour l'Emploi (PPE) Sim- ulation}

In this simulation we took the rules governing the PPE program ${ }^{29}$ at the start of 2006 (applicable to earnings in 2005), inflated our 1998 earnings to 2005 levels using purchasing power deflators, calculated eligibility and amounts of negative income tax payments, deflated them back to 1998 levels and added them to disposable income in the absence of intéressement case. Although the value of the transfer remains small overall, it is highest for individuals earning the equivalent of a full-time minimum wage, in contrast with intéressement payments (that decline to zero at that point). The PPE also benefits individuals employed on a CES contract.

The net result of all of these changes, as shown by table 5 , is that disposable income in work increases much more in this simulation, especially for men $(+10.38 \%)$ because they are more often working full-time. Employment now increases by $9 \%$ for men and $4 \%$ for women with respect to the baseline. By contrast, average transfers increase by only $4.9 \%$ and $3.5 \%$ respectively. This reform thus had the potential to bring about non-negligible changes in labor supply at relatively little additional cost to the government.

\subsubsection{Percent Minimum Wage Increase Simulation}

This last simulation looks at the impact of increasing the minimum wage by a significant amount, in our case 10 percent. ${ }^{30}$ The model allows for three different mechanisms by which such an increase can affect labor supply. First, and most straightforwardly, earnings in a minimum wage job increase by 10 percent (for a given number of hours worked). Second, the truncation point of the distribution of above-minimum wage jobs shifts upward, making expected earnings on non-minimum wage jobs higher as well. Finally, the value of a $C E S$ job (which is paid the minimum wage plus a top-up) also increases. The net impact on disposable income is limited, especially for

\footnotetext{
${ }^{29}$ The Prime Pour l'Emploi was introduced in 2001, with the objective of providing work incentives at the bottom of the income distribution to a large base of working households. It is not limited in time and is more generous than intéressement, especially for fulltime workers. For single persons, the premium represents $6 \%$ of labor earnings up to the equivalent of full-time work at the minimum wage; it then decreases linearly to 0 at 1.4 times the full-time minimum wage. Parents also receive a lump-sum transfer of 62 euros (in 1997 equivalents) per child. This transfer is cumulative with respect to other income sources, with few restrictions (a minimum of approximately 50 hour per moth worked and, for couples, a restriction on total household income).

${ }^{30}$ Our simulation holds constant the probability of receiving a minimum wage job offer when one does not receive a $C E S$ offer. Although there is significant work on the elasticity of employment with respect to movements in the minimum wage in France (Dolado et. al., 1996; Abowd et. al., 2000a; Abowd et. al., 2000b; Kramarz and Philippon, 2001), there is to our knowledge no work on the impact of minimum wage movements on the size of the spike at the minimum wage in the earnings distribution for France.
} 
women, by the high implicit tax rates on labor earnings and the resulting low elasticities with respect to wage.

The net result of a $10 \%$ increase in the minimum wage is an increase in disposable income of $7.35 \%$ for single men and $4.57 \%$ for single women in our simulations. The effects on the probability of employment are less than those of the PPE (a $6 \%$ increase for single men and a $2 \%$ increase for single women) but more than those of increasing intéressement indefinitely for men due to the fact that single men rarely receive intéressement payments. Interestingly, increasing the minimum wage also reduces net government transfers by $2.15 \%$ for men and by $1.0 \%$ for women. This is only partially driven by the increased employment probability. A secondary implication of minimum wage increases is that the difference between earnings when employed and the RMI threshold is also reduced, which lowers the amount the government must transfer as well. Whereas the former effect is more important for single men, the fact that women are more likely to have minimum (or low) wage jobs then men means that the second effect is likely to be more prevalent for single women. It is worth remembering that our simulation does not allow for demand-side effects of a minimum wage increase; as a result, the equilibrium outcome with respect to the probability of employment is uncertain.

\subsection{Discussion}

Overall, these structural estimates suggest that monetary incentives do affect labor supply in this population. Although potential gains from working are small on average for the whole population, selection effects are observed in the employed population and labor supply elasticities are of comparable size to those found elsewhere in the literature. That said, the in-work benefit program (intéressement) does not seem to provide particularly strong additional incentives to work, largely due to its time-limited nature and the relative small range of gross earnings that are eligible for the program.

It must be noted that this is a strict labor supply interpretation of the basic facts presented in the previous sections, although our estimation of the job offer distribution partially captures demand-side phenomena. In the theoretical model, we do not allow the possibility that job offers may not be proposed at all to certain welfare recipients. It could be argued that individuals with more productive characteristics are also more likely to receive offers. In our specification, the negative values of the intercept (table 4) can be interpreted as implying that no work is preferred to very poorly paid, short-hours work. If we were to incorporate a probability of receiving a job offer into our model at all, it would only be identified separately from this intercept under strong additional conditions ${ }^{31}$ that would not be empirically relevant in our data. Our implicit assumption is rather that a job can always

\footnotetext{
${ }^{31}$ Laroque and Salanié (2003) use an "ad infinitum" type of reasoning to justify their identification of the probability of receiving a job offer.
} 
be found (and represented by a draw from the distribution $\left.\left(w^{d}, h^{d} \mid X\right)\right)$, but that the offer may be so unattractive that most individuals would be reluctant to take it. Such an assumption is compatible with sociological field analysis of this population (Benarrosh, 2003).

Finally, note that our likelihood function implicitly assumes that welfare beneficiaries only make one draw from the job offer distribution which they may take or leave. This is very much in line with the static approach to labor supply. In contrast, Dickens and Lundberg (1993) allow workers to choose among a random number of offers. In such a context, those who had the opportunity to choose between a larger number of alternatives would select jobs with higher earnings and would therefore be more often observed in employment. However, for the purpose of estimating the sensitivity of preferences to disposable income, assuming (1) that some people have a chance to draw a high wage or assuming (2) that some people have a chance to make a large number of draws, among which there is more often a high wage, are functionally equivalent.

\section{Conclusion}

The evaluation of potential labor earnings for recipients of a guaranteed minimum income transfer (such as the French RMI system) is a conceptually and technically delicate exercise. It remains, nevertheless, an indispensable piece of information in the debate concerning the incentive effects on labor supply of welfare. Simulations for "representative households" and calculations based exclusively on estimated effective marginal tax rates are inadequate, in that they do not account for the heterogeneity in labor market conditions that RMI recipients face. In this paper, we have considered the interaction between the labor market and the system of taxes and transfers in effect in France in 1998 (with the exception of local taxes and local transfers) accounting for the presence of the supplemental earnings top-up provided by the welfare system under the name of intéressement. Since RMI recipients tend to be very different from the population as a whole in terms of their reemployment labor earnings, it is important to use an RMI-centered survey to obtain reasonable sample sizes of the population of interest. But since the sorts of jobs to which RMI recipients can aspire tend to be rather particular, most notably due to the predominance of active labor market programs (such as France's CES jobs), it becomes essential to specify a model to predict wage and hours offers that fits the observed data on welfare recipients as well as possible.

We find that almost all welfare beneficiaries would gain from being employed on a job randomly drawn from the distribution of job offers, relative to staying on welfare. But the size of the gains is extremely small. As of 1998, the intéressement scheme provided only marginal additional incentives 
due to its time-limited nature. This may be part of the reasoning behind the modification of the rules governing the intéressement scheme in 1998 and 2001 which extend its applicability from 750 hours to about one year and reduce the implicit marginal tax rate from $50 \%$ to $0 \%$ during the first three months. Most strikingly, the monetary work incentives for single mothers are very limited. Were we able to directly integrate child care costs and locally available means-tested assistance policies, we would almost surely find a net loss associated with work for French single mothers.

We find that the distribution of gains that we estimate for the population of individuals actually observed in employment differs from that of those individuals observed out of employment at the time of the follow-up survey. We interpret this as a labor supply effect and quantify it based on a simple structural employment model, although some of our point estimates are imprecise, in part due to the high degree of collinearity between disposable income and hours worked. Our estimated extensive margin labor supply elasticities, in the range of 1.25 to 0.39 for men and 1.10 to 0.44 for women (depending on the specification) are quite comparable to extensive margin labor supply elasticities estimated on similar populations elsewhere in the United States- and France-based literature, and our policy simulations suggest that although the intéressement program may not be the ideal mechanism for increasing labor supply among welfare recipients, other policy instruments (such as the Prime Pour l'Emploi negative income tax, implemented in France in 2001) are more promising. Alternatively, the estimated preference for full time work suggests that a policy aimed at increasing the supply of these sorts of jobs might be particularly effective.

Overall, it appears that French welfare recipients are relatively sensitive to monetary incentives when making labor supply decisions, but the existing system only provides limited incentives for welfare recipients to work. Our policy simulations suggest that changing the structure of the monetary incentives has the potential to bring quite a few additional individuals off of welfare and into work, and the cost to the government of providing these incentives may not be prohibitive.

The authors are grateful to Cédric Afsa for his numerous comments, Thomas Piketty and two anonymous referees for helpful suggestions and Luc Behaghel for outstanding research assistance. They would also like to thank Danièle Guillemot for helping provide access to the data and Cyril Hagneré for help into the French welfare system, as well as Jean-Claude Barbier, Jérôme Gautié, Guy Laroque, Laurence Rioux, Bernard Salanié, Daniel Szpiro and participants at the DREES workshop, the "Working Poor en France" conference and seminars at the Centre d'Etudes de l'Emploi, Université Lille I and Université Catholique de Louvain for their comments. This research was financed by a grant from the Ministry of Labour. 


\section{Bibliography}

Abowd, John M., Francis Kramarz, Thomas Lemieux and David N. Margolis (2000a). "Minimum Wages and Youth Employment in France and the United States," in David G. Blanchflower and Richard B. Freeman (eds.), Youth Employment and Joblessness in Advanced Countries, (Cambridge: NBER).

Abowd, John M., Francis Kramarz, David N. Margolis and Thomas Philippon (2000b). "The Tail of Two Countries: Minimum Wages and Employment in France and the United States," IZA Discussion Paper, no. 203, September.

Altonji, Joseph G. and Christina H. Paxson (1988). "Labor Supply Preferences, Hours Constraints, and Hours-Wage Trade-Offs," Journal of Labor Economics, vol. 6, pp. 254-276.

Altonji, Joseph G. and Christina H. Paxson (1992). "Labor Supply, Hours Constraints, and Job Mobility," Journal of Human Resources, vol. 27, pp. 256-278.

Benarrosh, Yolande (2003), "Les trappes d'inactivité - Chômage volontaire ou chômage de résistance ?", Travail et emploi, no 95.

CNAF (1996a), 1996, statistiques CAF et tous régimes, Série "Prestations familiales".

CNAF (1996b), Revenu minimum d'insertion au 31 décembre 1996, Série "Recherche, prévision, statistique".

CSERC (1999). Le SMIC: Salaire Minimum de Croissance, (Paris: La Documentation Française).

Dickens, William and Shelly Lundberg (1993), "Hours Restrictions and Labor Supply", International Economic Review, vol. 34, pp. 169-192.

Dolado, Juan, Francis Kramarz, Steven Machin, Alan Manning, David N. Margolis and Coen Teulings (1996), "The Economic Impact of Minimum Wages in Europe," Economic Policy, October.

Eissa, Nada, Henrik Jacobsen Kleven and Claus Thustrup Kreiner (2004), "Evaluation of Four Tax Reforms in the United States: Labor Supply and Welfare Effects for Single Mothers," NBER Working Paper no. 10935, November.

Euwals, Rob and Arthur van Soest (1999), "Desired and Actual Labor Supply of Unmarried Men and Women in the Netherlands", Labour Economics, vol. 6, pp. 95-118.

Fougère, Denis and Laurence Rioux (2001), "Le RMI treize ans après: entre redistribution et incitations", Economie et statistique, no. 346-347, 2001-6/7, pp. 3-12.

Galtier, Bénédicte (1999), "Les temps partiels : entre emplois choisis et emplois 'faute de mieux'," Economie et statistique, no. 321-322, 1999-1/2 , pp. $57-77$. 
Gautié, Jérôme and Alain Gubian (2000), "Réforme du revenu minimum d'insertion et marché du travail," Droit social, no. 7-8, juillet-août, pp. 699707.

Gilles-Simon, Marie-Odile and Michel Legros (1996), "Le non-recours chez les plus pauvres: une approche empirique", Recherches et prévision, no. 43 , pp. 51-58.

Gravel Nicolas, Cyrille Hagneré and Nathalie Picard (2004). "Une estimation des conséquences d'une réforme des minima sociaux sur l'offre de travail à l'aide d'un modèle intertemporel de microsimulation, Economie Publique, no. 14

Gurgand, Marc and David N. Margolis (2000), "Minima sociaux et revenus du travail en France," Document de travail 2000-62, CREST, INSEE.

Gurgand, Marc and David N. Margolis (2002), "A Multiple-State NonStationary Model of Welfare Exit", presented at the 2003 European Association of Labour Economists Annual Conference, May.

Hagneré, Cyrille, Nathalie Picard, Alain Trannoy and Karine Van der Straeten (2003). "L'importance des incitations financières dans l'obtention d'un emploi est-elle surestimée ?" Economie et Prévision, no. 160-161.

Hagneré, Cyrille and Alain Trannoy (2001). "L'impact de trois ans de réforme sur les trappes à inactivité," Economie et Statistique no. 346-347, p.161-185.

Hajivassiliou, Vassilis and Paul Ruud (1994), "Classical Estimation Methods for LDV Models using Simulation", Handbook of Econometrics, vol. 4, (Amsterdam: North-Holland).

Heckman, James J. (1979), "Sample selection bias as a specification error," Econometrica, vol. 47, pp. 153-161.

Join-Lambert, Marie-Thérèse (1998), Chômage: mesures d'urgence et minima sociaux, (Paris: La Documentation française).

Kahn, Shulamit and Kevin Lang (1991). "The Effect of Hours Constraints in Labor Supply Estimates," Review of Economics and Statistics, vol. 73, pp. 605-611.

Kahn, Shulamit and Kevin Lang (1996). "Hours Constraints and the Wage/Hours Locus," Canadian Journal of Economics, vol. 29, pp. S71-S75.

Kramarz, Francis and Thomas Philippon (2001), "The Impact of Differential Payroll Tax Subsidies on Minimum Wage Employment," Journal of Public Economics, vol. 82, pp. 115-146.

Laroque, Guy and Bernard Salanié (1999), "Prélèvements et transferts sociaux : une analyse descriptive des incitations financières au travail," Economie et statistique, no. 328, 1999-8, pp. 3-19.

Laroque, Guy and Bernard Salanié (2002), "Labour Market Institutions and Employment in France", Journal of Applied Econometrics, 17(1), pp. $25-48$.

Laroque, Guy and Bernard Salanié (2003), Institutions et emploi: Les femmes et le marché du travail en France, (Paris: Economica). 
L'Horty, Yannick (2006). Les nouvelles politiques de l'emploi, (Paris: Editions La Découverte).

L'Horty, Yannick and Denis Anne (2002), "Transferts sociaux locaux et retour à l'emploi," Economie et statistique, no 357-358, pp. 42-71.

Lhommeau, Bertrand (2002), "Les configurations familiales des ménages comptant un allocataire du RMI : du foyer RMI au ménage INSEE," Economie et statistique.

Liaisons sociales (1998), Barême social périodique, January.

Margolis, David N. (1996), "Cohort Effects and Returns to Seniority in France," Annales d'Economie et de Statistique, January/June.

Meyer, Bruce D. and Dan T. Rosenbaum (2001), "Welfare, the Earned Income Tax Credit, and the Labor Supply of Single Mothers," Quarterly Journal of Economics, August, pp. 1063-1114.

Moffitt, Robert (2002), "Welfare Programs and Labor Supply", in Alan J. Auerbach and Martin Feldstein (eds.), Handbook of Public Economics, volume 4 (Amsterdam: North Holland), pp. 2393-2430.

Moffitt, Robert (2003), "The Negative Income Tax and the Evolution of U.S. Welfare Policy", Journal of Economic Perspectives, Summer, pp. 119140 .

OECD (1995), Employment Outlook: 1995 Edition, OECD, Paris.

OECD (2003), Employment Outlook: 2003 Edition, OECD, Paris.

Padieu, C. (1997), "RMI et Smic: étude sur l'apport financier de l'accès à l'emploi par types de ménages", Les Cahiers de l'ODAS, mars.

Piketty, Thomas (1998). "L'impact des incitations financières au travail sur les comportements individuels: une estimation pour le cas français," Economie et prévision, no. 132-133, pp. 1-35.

Piketty, Thomas (2005). "L'impact de l'allocation parentale d'éducation sur l'activité feminine et la fécondité en France, 1982-2002," in Cécile Lefevre (ed.), Histoires de familles, histoires familiales, Les Cahiers de l'INED, no. 156, pp. 79-109.

Rémy, Véronique (2005), "Elements de bilan sur les travaux évaluant l'efficacité des allègements de cotisations sociales employeurs," Document d'études DARES, number 101, juillet.

Roux, Sébastien (2005), "L'augmentation du temps partiel est-elle déterminée par les entreprises ou par les travailleurs?", INSEE mimeo, Paris.

Saez, Emmanuel (2002), "Optimal Income Transfer Programs: Intensive versus Extensive Labor Supply Responses," Quarterly Journal of Economics, vol. 117, pp. 1039-1073.

Stewart, Mark B. and Joanna K. Swaffield (1997). "Constraints on the Desired Hours of Work of British Men," Economic Journal, vol. 107, pp. $520-534$.

Terracol, Antoine (2003), Essais sur la perception des minima sociaux en France, Ph.D. Dissertation, Université Paris 1 Panthéon-Sorbonne, Paris, France. 
van Soest, Arthur, (1995), "Structural Models of Family Labor Supply. A Discrete Choice Approach", Journal of Human Resources, vol. 30, no 1, pp. 63-88.

Zoyem, Jean-Paul (1999), "Contrat d'insertion et sortie du RMI", Document de travail G 9909, Direction des études et synthèses économiques, INSEE. 


\section{A The French Welfare System}

The main component of France's welfare system at the national level is the Revenu Minimum d'Insertion (RMI), a guaranteed minimum income program accessible to any person aged 25 and over, ${ }^{32}$ provided that the sum of all resources available to his or her household is below a threshold that depends on family composition. These take the form of a monetary transfer that brings household resources up to the threshold. Other guaranteed income programs (with restricted access) do exist, such as those for the elderly, handicapped, widows and widowers and single parents with children below $3 .^{33}$ These other programs are typically more generous than RMI, and the transfers for the handicapped and the elderly cover a large number of people, while the population covered by the widow/widower benefits is rather limited. However, the role of these transfers in affecting the labor market behavior of those concerned is likely to be quite different from that of the RMI. Finally, the unemployed who have exhausted their unemployment benefits have access to a specific benefit whose amount is similar to that of RMI. ${ }^{34}$

When comparing labor income with welfare income, additional transfers related to family composition and housing must be considered. Most family composition-based benefits are means tested, increase with the number of children, and vary with the presence or absence of children under 3 years old. ${ }^{35}$ We exclude the Allocation parentale d'éducation, or $A P E{ }^{36}$ which is available to every household with at least 2 children of which one is less than 3 years old, provided one of the spouses does not work or works part time and can justify at least 2 years of work over the last 5 or 10 years (depending on the number of children). This last benefit was being paid to roughly 300,000 French women with 2 children (for which the amount was roughly 365 Euros/month) and roughly 180,000 French women with 3 or more children (for which the amount was roughly 450 Euros/month) on December 31, 1997 (Piketty, 2005). We cannot consider this benefit because information on past employment in the data is insufficient to determine eligibility. Although Piketty (1998) has shown that this transfer has significant labor supply effects (up to half of the recipients of this program may have withdrawn from the

\footnotetext{
${ }^{32}$ This age restriction does not apply for people with underage dependents.

${ }^{33}$ This last benefit, called the Allocation du Parent, or API, cannot be received for more than 3 years total.

${ }^{34}$ Unfortunately, our data does not allow us to observe individuals who receive the single parents with young children benefit or the transfer in the event of unemployment benefit exhaustion.

${ }^{35}$ In particular, every household responsible for at least 2 children is entitled to a transfer (Allocations familiales). The additional, means-tested, transfers considered in this paper are the Complement familial, Allocation pour jeune enfant and Allocation de rentrée scolaire.

${ }^{36}$ A subsidy for children in school which was introduced in 1995 (Aide à la scolarité) is also not considered here.
} 
labor force due to its disincentive effects), it is not particularly relevant for our data. First, the transfers are well below the RMI threshold for single persons with the corresponding number of children, so that no single should claim it. As a result, the labor supply section of the paper is not sensitive to this. For couples, this scheme has the potential to increase disincentives, but only in particular segments of the potential earnings distribution of the wife and husband. This implies that although we may understate disincentives in the "gains to employment" computations, this problem is likely to occur only in what is likely to be a small (but unknowable in our data) share of couples in which one of the spouses has sufficient work experience to qualify.

\section{B Econometric Specification}

In order to further investigate the link between gains to employment and observed employment, we estimate the structural model based on equation 1. Taking simple functional forms for the utility functions, we set:

$$
U\left(D\left(w h, y_{0}, Z\right), h ; Z, \varepsilon\right)=\alpha \log D\left(w h, y_{0}, Z\right)+k(h)+Z \delta+\varepsilon
$$

when working, and:

$$
U\left(D\left(0, y_{0}, Z\right), 0 ; Z, \varepsilon\right)=\alpha \log D\left(0, y_{0}, Z\right)+k(0)+Z \delta_{0}+\varepsilon_{0}
$$

if not working. We normalize $k(0)=\delta_{0}=\varepsilon_{0}=0$ and $\operatorname{var}(\varepsilon)=1$. This implies that all parameters, but $\alpha$, must be interpreted as measuring an effect relative to non-working. In practice, function $k(h)$ will be either $\beta \log h$ or $\beta$ times an indicator variable for more than 130 monthly hours. Assuming that $\varepsilon$ is independent of $\left(w^{d}, h^{d} \mid X\right),{ }^{37}$ the contribution to the likelihood for working individuals is:

$$
\begin{aligned}
& P\left(\text { Employment at } w, h \mid X, Z, y_{0}\right)=P\left(\varepsilon \geq \alpha\left[\log D\left(0, y_{0}, Z\right)\right.\right. \\
& \left.-\log D\left(w h, y_{0}, Z\right)\right] \\
& -k(h)-Z \delta) \\
& \times f(w, h \mid X)
\end{aligned}
$$

and for non-working individuals:

$$
\begin{array}{rr}
P\left(\text { Non-Employment } \mid X, Z, y_{0}\right)=\int_{w^{d}} \int_{h^{d}} & P\left(\varepsilon<\alpha\left[\log D\left(0, y_{0}, Z\right)\right.\right. \\
& \left.-\log D\left(w^{d} h^{d}, y_{0}, Z\right)\right] \\
& \left.-k\left(h^{d}\right)-Z \delta\right) \\
& \times f\left(w^{d}, h^{d} \mid X\right) d w^{d} d h^{d}
\end{array}
$$

\footnotetext{
${ }^{37}$ This technical assumption, also made by van Soest (1995), simplifies the estimation by allowing us to estimate sequentially the job offer distribution and labor supply.
} 
where the joint distribution $f\left(w^{d}, h^{d} \mid X\right)$ has been estimated as described below. The assumption of independence between $\varepsilon$ and $\left(w^{d}, h^{d} \mid X\right)$ means that we can just condition on realized $(w, h)$, instead of the full density, when maximizing the likelihood function.

\section{B.1 Estimation of the Joint Wage-Hours Distribution}

Given the considerations described in section 3.2, we estimate the following statistical models.

A CES is proposed when

$$
X \beta_{C}+u_{C} \geq 0
$$

If a CES offer is not received, a "regular job" wage is drawn. It is paid the minimum wage, $w=\underline{w}$, if

$$
X \beta_{S}+u_{S} \geq 0
$$

Otherwise, the wage is drawn in a truncated wage distribution with density

$$
f_{w}(w \mid w>\underline{w})=f_{w}(w) / P(w>\underline{w})
$$

and the underlying density of $w$ is generalized logistic:

$$
f_{w}(w)=\frac{\exp ((w-m) / s)}{s(1+\exp ((w-m) / s))^{2}}
$$

where parameters $m$ and $s$ are estimated.

Hours worked can be drawn from a full-time distribution or a part time distribution. If

$$
X \beta_{H}+u_{H} \geq 0
$$

then hours is drawn from a full-time truncated distribution with density

$$
f_{1 h}(h \mid h>0, h \leq \bar{h})=f_{1 h}(h) / P(h>0, h \leq \bar{h})
$$

where $\bar{h}$ is the maximum working time. ${ }^{38}$ Otherwise, the hours worked are drawn from the part time density $f_{2 h}(h \mid h>0, h \leq \bar{h})$, defined in a similar manner. The underlying densities are also generalized logistic:

$$
f_{i h}(h)=\frac{\exp \left(\left(h-m_{i}\right) / s_{i}\right)}{s_{i}\left(1+\exp \left(\left(h-m_{i}\right) / s_{i}\right)\right)^{2}}, \quad i=1,2
$$

\footnotetext{
${ }^{38}$ As we have no a priori knowledge of the maximum monthly working time of the set of offered jobs, we used the sample maximum for each sex to define $\bar{h}$, which is the best nonparametric estimator of this parameter. For men, $\bar{h}=312$, while for women, $\bar{h}=333$.
} 
We set $m_{1}=169$, the standard full-time monthly hours worked and $m_{2}=87$, the standard half-time hours worked. Parameters $s_{1}$ and $s_{2}$ are estimated.

Finally, in order to account for the selectivity into employment, we assume that a reduced form to equation 1 can be approximated by

$$
\left(X, Z, D_{0}\left(0, y_{0}, Z\right)\right) \gamma+\eta \geq 0
$$

Although this linear approximation is questionable with respect to the structural interpretation of the equation, it must be clear that, at this stage, this equation is only meant to control for selectivity, using variables in $Z$ excluded from $X$.

All residuals $\left(u_{C}, u_{S}, u_{H}, \eta\right)$ are assumed to be jointly normally distributed. However, it was necessary to impose the constraints $\rho_{u_{C}, u_{S}}=0$ and $\rho_{u_{C}, u_{H}}=$ 0 in order to obtain convergence. Intuitively, these constraints mean that we suppose that the unobserved characteristics that make an individual disproportionately likely to be selected for a CES contract are uncorrelated with the unobserved characteristics that make the same individual more or less likely to find a minimum wage or a part time job. Such an assumption is not unreasonable given the institutional context, since it is typically the case workers that serve as intermediaries between RMI recipients and $C E S$ contract proposers (who are necessarily public sector employers), whereas it is the market that sorts individuals into minimum wage and part time work.

Because of data limitations, we were forced to adopt a very simple specification for the structural estimation. For women, the only control variables in the $Z$ vector are age and the number of children in three age classes. For men, only age is maintained because the number of children appeared irrelevant. The potential gains (expressed in logarithms) are computed using the baseline scenario. The model is estimated by simulated maximum likelihood, using 500 draws to estimate the joint distribution of $\left(w^{d}, h^{d} \mid X\right)$ in the evaluation of the double integral in equation 4 and assuming a standard normal distribution for $\varepsilon .^{39}$

\section{The Data}

We use the Outcomes for RMI Recipients Survey (Devenir des personnes sorties du RMI, see Fougère and Rioux, 2001), which was undertaken by the French National Institute for Statistics and Economic Studies (INSEE) in collaboration with several other public institutions. A representative sample of RMI recipients was drawn and surveyed in December of 1996 and a follow-up survey was then administered one year later, in January 1998. We exploit this second cross-section which includes, along with demographic and

\footnotetext{
${ }^{39}$ Note that the standard errors reported in this table are not corrected for the presence of estimated regressors, notably the gains to employment and the hours offer for people not observed in employment.
} 
household characteristics, information concerning the employment status of the person, in particular his or her monthly earnings and hours (if employed) as well as all of the information necessary to reconstruct the other transfers for which the household is eligible. This last point is particularly important, since the housing subsidies introduce a highly nonlinear, and sometimes discontinuous, relation between labor earnings and disposable income (see section 2); it is thus critical to be able to identify precisely the households that have access to this subsidy and to adjust their disposable income accordingly.

Residual eligibility for intéressement payments at the follow-up survey date is not directly measured. Nevertheless, it depends on the time spent working in the past months or years, according to a complex set of rules. We use activity calendars to calculate the number of hours during which each individual may still be eligible for intéressement payments as of January 1998. We were able to reconstruct this information for $87 \%$ of the sample. By construction, the remaining $13 \%$ are individuals with neither long periods of employment nor long periods of non-employment over the past year. ${ }^{40}$ When eligibility is available, we find that $72 \%$ of the population has the opportunity to benefit the RMI top-up for the full 750 hours, whereas $19 \%$ has exhausted this possibility and would get the disposable incomes drawn on the bottom lines of figures 1 and 2 . The remaining $9 \%$ is eligible, but for less than 750 hours, with residual hours distributed rather smoothly. These figures are decomposed by gender in the Appendix table.

We use the survey both to estimate the structure of wages and hours available to RMI recipients and to simulate the potential gains to employment for the entire population of RMI recipients. We restrict our attention to people between 17 and 55 years old, and we exclude students and retirees and some missing observations, which leaves us with 2,764 beneficiaries. Descriptive statistics are presented in Appendix tables 1 and 2. We also eliminate selfemployment for the estimation of potential income. We assume 100 percent take-up of transfers for which the household is eligible in the simulations. ${ }^{41}$ This provides us with a lower bound on the gains from employment. In order to avoid the complicated issue of simultaneous labor supply decision making within households, couples are excluded from the sample when we examine the link between gains to employment and observed employment. ${ }^{42}$

The data is also subject to measurement error with respect to reported earnings and hours. Monthly earnings as well as usual weekly hours are

\footnotetext{
${ }^{40}$ The subsamples for which residual intéressement rights can and cannot be calculated are roughly similar on the basis of observable characteristics, and as a result we perform the majority of our analyses only on the sample for which we are able to reconstruct residual rights to intéressement payments.

${ }^{41}$ Our data do not contain sufficient information to measure take-up rates accurately. See Gilles-Simon and Legros (1996) and Terracol (2003) for analyses of benefit take-up in France.

${ }^{42}$ Individuals in couples do, however, contribute to the estimation of the wage and hours offer distributions.
} 
recorded by the survey. It appears that a significant portion (roughly one third) of the hourly wage rates computed from this information lie below the minimum wage. Most of these inconsistencies are obviously due to rounding errors and the fact that relatively few individuals in the sample are paid above from the minimum wage in this population. Thus, whenever reported hourly wages fall below the minimum wage, we assume that monthly earnings are more reliable than monthly hours, set the hourly wage to the minimum wage and recompute hours based on reported monthly earnings so as to be compatible with existing minimum wage laws. 
Table 1 : Results of Selection-Corrected CES and Wage - Working Time Models

\begin{tabular}{|c|c|c|c|c|c|c|c|}
\hline \multicolumn{8}{|c|}{ Men } \\
\hline & Selection & & CES & & Min. wag & & Full-time work \\
\hline Intercept & $\begin{array}{l}-0,7140 \\
(0,1358)\end{array}$ & **** & $\begin{array}{l}-1,1522 \\
(0,1256)\end{array}$ & **** & $\begin{array}{c}1,0296 \\
(0,4426)\end{array}$ & ** & $\begin{array}{c}0,4126 \\
(0,6342)\end{array}$ \\
\hline Age & $\begin{array}{l}-0,8298 \\
(0,4046)\end{array}$ & ** & $\begin{array}{l}-0,2377 \\
(0,4330)\end{array}$ & & $\begin{array}{c}0,1595 \\
(0,8186)\end{array}$ & & $\begin{array}{l}-1,2293 \\
(0,9280)\end{array}$ \\
\hline $\mathrm{Age}^{2}$ & $\begin{array}{c}0,5179 \\
(0,4093)\end{array}$ & & $\begin{array}{c}0,0733 \\
(0,4369)\end{array}$ & & $\begin{array}{l}-0,1164 \\
(0,8226)\end{array}$ & & $\begin{array}{c}1,2283 \\
(0,9378)\end{array}$ \\
\hline French Nationality & $\begin{array}{l}-0,0811 \\
(0,1148)\end{array}$ & & $\begin{array}{l}-0,1623 \\
(0,1258)\end{array}$ & & $\begin{array}{l}-0,3367 \\
(0,2609)\end{array}$ & & $\begin{array}{l}-0,1594 \\
(0,3015)\end{array}$ \\
\hline Paris Region & $\begin{array}{l}-0,1829 \\
(0,1161)\end{array}$ & & $\begin{array}{l}-0,5570 \\
(0,1747)\end{array}$ & **** & $\begin{array}{l}-0,2518 \\
(0,2773)\end{array}$ & & $\begin{array}{c}0,2077 \\
(0,2714)\end{array}$ \\
\hline Education Category 1 (higher) & $\begin{array}{c}0,6280 \\
(0,1424)\end{array}$ & *** & $\begin{array}{l}-0,1067 \\
(0,1811)\end{array}$ & & $\begin{array}{l}-0,6378 \\
(0,3285)\end{array}$ & * & $\begin{array}{l}-0,3982 \\
(0,3975)\end{array}$ \\
\hline Education Category 2 (upper sec.) & $\begin{array}{c}0,3893 \\
(0,1470)\end{array}$ & **** & $\begin{array}{l}-0,0841 \\
(0,1825)\end{array}$ & & $\begin{array}{c}0,0823 \\
(0,3527)\end{array}$ & & $\begin{array}{c}0,0143 \\
(0,3892)\end{array}$ \\
\hline Education Category 3 (lower sec.) & $\begin{array}{l}-0,0645 \\
(0,1390)\end{array}$ & & $\begin{array}{c}0,0100 \\
(0,1470)\end{array}$ & & $\begin{array}{l}-0,0019 \\
(0,3245)\end{array}$ & & $\begin{array}{l}-0,2104 \\
(0,3642)\end{array}$ \\
\hline Education Category 4 (vocational) & $\begin{array}{c}0,2713 \\
(0,1229)\end{array}$ & ** & $\begin{array}{c}0,1350 \\
(0,1362)\end{array}$ & & $\begin{array}{l}-0,2508 \\
(0,2915)\end{array}$ & & $\begin{array}{c}0,2018 \\
(0,3432)\end{array}$ \\
\hline $\log \left(D_{0}\left(0, y_{0}, Z\right)\right)$ & $\begin{array}{c}0,0263 \\
(0,0750)\end{array}$ & & & & & & \\
\hline Number of Children: 0-2 Years Old & $\begin{array}{l}-0,0436 \\
(0,0427)\end{array}$ & & & & & & \\
\hline Number of Children: 3-14 Years Old & $\begin{array}{l}-0,0479 \\
(0,0530)\end{array}$ & & & & & & \\
\hline Number of Children: $15+$ Years Old & $\begin{array}{c}0,0782 \\
(0,0421)\end{array}$ & * & & & & & \\
\hline Couple & $\begin{array}{c}0,3266 \\
(0,1474)\end{array}$ & *** & & & & & \\
\hline Widow & $\begin{array}{c}0,2708 \\
(0,4140)\end{array}$ & & & & & & \\
\hline Divorced & $\begin{array}{c}0,1614 \\
(0,1432)\end{array}$ & & & & & & \\
\hline
\end{tabular}

Wage and hours dist. parameters

m

$s$

$\mathrm{S}_{1}$

$\mathrm{s}_{2}$

$\rho_{\text {Employment,CES }}$

$\rho_{\text {Minimum Wage, Working Time }}$

$\rho_{\text {Employment, Minimum Wage }}$

$\rho_{\text {Employment, Working Time }}$
3,3704
$(0,1895)$
0,1711
$(0,0275)$

2,8649

$(0,2344)$

60,4063

$(8,2833)$

0,9981

$(0,1608)$

$-0,2146$

$(0,1865)$

$-0,4105$

$(0,4020)$

$-0,1806$

$(0,5134)$

\# observations 1303

Source: Authors' estimates using the Devenir des personnes sorties du RMI survey. Standard errors are in parentheses. Standard errors of estimates of constrained parameters $\left(s, s_{1}, s_{2}\right.$ and the various $\left.\rho\right)$ obtained using the delta method. ${ }^{* * *}$ indicates a coefficient significant at the $1 \%$ level, $* *$ indicates a coefficient signficant at the $5 \%$ level and $*$ indicates a coefficient significant at the $10 \%$ level. 
Table 1 (Continued): Results of Selection-Corrected CES and Wage - Working Time Models

\begin{tabular}{|c|c|c|c|c|c|c|c|c|}
\hline \multicolumn{9}{|c|}{ Women } \\
\hline & Selection & & CES & & Min. wage & & Full-time wo & \\
\hline Intercept & $\begin{array}{c}-0,7189 \\
(0,1650)\end{array}$ & **** & $\begin{array}{l}-0,6495 \\
(0,4596)\end{array}$ & & $\begin{array}{c}1,0297 \\
(0,4738)\end{array}$ & ** & $\begin{array}{l}-1,2948 \\
(0,5563)\end{array}$ & *** \\
\hline Age & $\begin{array}{l}-0,0865 \\
(0,3555)\end{array}$ & & $\begin{array}{c}0,9233 \\
(0,1793)\end{array}$ & $* * *$ & $\begin{array}{l}-1,6578 \\
(0,9105)\end{array}$ & * & $\begin{array}{l}-1,0051 \\
(1,1546)\end{array}$ & \\
\hline $\mathrm{Age}^{2}$ & $\begin{array}{l}-0,0259 \\
(0,3566)\end{array}$ & & $\begin{array}{l}-1,1507 \\
(0,1679)\end{array}$ & *** & $\begin{array}{c}1,7457 \\
(0,9071)\end{array}$ & * & $\begin{array}{c}0,6519 \\
(1,2394)\end{array}$ & \\
\hline French Nationality & $\begin{array}{c}-0,0708 \\
(0,1404)\end{array}$ & & $\begin{array}{l}-0,0381 \\
(0,2440)\end{array}$ & & $\begin{array}{l}-0,0250 \\
(0,3234)\end{array}$ & & $\begin{array}{c}-0,1902 \\
(0,4287)\end{array}$ & \\
\hline Paris Region & $\begin{array}{l}-0,0073 \\
(0,1252)\end{array}$ & & $\begin{array}{l}-1,0405 \\
(0,2799)\end{array}$ & $* * *$ & $\begin{array}{c}-0,1011 \\
(0,2119)\end{array}$ & & $\begin{array}{c}0,4475 \\
(0,2411)\end{array}$ & * \\
\hline Education Category 1 (higher) & $\begin{array}{c}0,8201 \\
(0,1513)\end{array}$ & *** & $\begin{array}{l}-0,3595 \\
(0,3259)\end{array}$ & & $\begin{array}{l}-0,9690 \\
(0,3141)\end{array}$ & *** & $\begin{array}{c}0,6905 \\
(0,4731)\end{array}$ & \\
\hline Education Category 2 (upper sec.) & $\begin{array}{c}0,7031 \\
(0,1421)\end{array}$ & *** & $\begin{array}{l}-0,0706 \\
(0,2945)\end{array}$ & & $\begin{array}{l}-0,2176 \\
(0,3363)\end{array}$ & & $\begin{array}{l}-0,1503 \\
(0,5309)\end{array}$ & \\
\hline Education Category 3 (lower sec.) & $\begin{array}{c}0,2055 \\
(0,1252)\end{array}$ & & $\begin{array}{c}0,0654 \\
(0,2337)\end{array}$ & & $\begin{array}{c}-0,1392 \\
(0,2872)\end{array}$ & & $\begin{array}{l}-0,4740 \\
(0,5223)\end{array}$ & \\
\hline Education Category 4 (vocational) & $\begin{array}{c}0,4135 \\
(0,1204)\end{array}$ & $* * *$ & $\begin{array}{c}0,1091 \\
(0,2414)\end{array}$ & & $\begin{array}{c}0,1031 \\
(0,3122)\end{array}$ & & $\begin{array}{c}-0,1118 \\
(0,5063)\end{array}$ & \\
\hline $\log \left(D_{0}\left(0, y_{0}, Z\right)\right)$ & $\begin{array}{c}0,1838 \\
(0,0648)\end{array}$ & ${ }^{* * *}$ & & & & & & \\
\hline Number of Children: 0-2 Years Old & $\begin{array}{l}-0,3549 \\
(0,0576)\end{array}$ & *** & & & & & & \\
\hline Number of Children: 3-14 Years Old & $\begin{array}{l}-0,1364 \\
(0,0602)\end{array}$ & ** & & & & & & \\
\hline Number of Children: $15+$ Years Old & $\begin{array}{l}-0,0501 \\
(0,0446)\end{array}$ & & & & & & & \\
\hline Couple & $\begin{array}{l}-0,4618 \\
(0,1133)\end{array}$ & *** & & & & & & \\
\hline Widow & $\begin{array}{l}-0,5580 \\
(0,2338)\end{array}$ & ** & & & & & & \\
\hline Divorced & $\begin{array}{l}-0,0740 \\
(0,0986)\end{array}$ & & & & & & & \\
\hline \multicolumn{9}{|l|}{ Wage and hours dist. parameters } \\
\hline 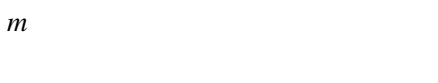 & & & & & $\begin{array}{c}3,4005 \\
(0,1935)\end{array}$ & *** & & \\
\hline$s$ & & & & & $\begin{array}{c}0,1981 \\
(0,0349)\end{array}$ & *** & & \\
\hline $\mathrm{s}_{1}$ & & & & & & & $\begin{array}{c}2,5135 \\
(0,3361)\end{array}$ & **** \\
\hline $\mathrm{s}_{2}$ & & & & & & & $\begin{array}{l}38,6605 \\
(3,1113)\end{array}$ & *** \\
\hline$\rho_{\text {Employment, CES }}$ & $\begin{array}{c}0,4028 \\
(0,2714)\end{array}$ & & & & & & & \\
\hline$\rho_{\text {Minimum Wage, Working Time }}$ & $\begin{array}{l}-0,3294 \\
(0,1767)\end{array}$ & * & & & & & & \\
\hline$\rho_{\text {Employment, Minimum Wage }}$ & $\begin{array}{l}-0,5487 \\
(0,2921)\end{array}$ & * & & & & & & \\
\hline$\rho_{\text {Employment, Working Time }}$ & $\begin{array}{c}0,5592 \\
(0,3021)\end{array}$ & * & & & & & & \\
\hline \# observations & 1461 & & & & & & & \\
\hline
\end{tabular}


Table 2: Gains to Work by Household Type

\begin{tabular}{lcccccc}
\hline & \multicolumn{6}{c}{ Total monthly gains } \\
\cline { 2 - 7 } & \multicolumn{5}{c}{ Baseline simulation } & \multicolumn{3}{c}{ Without Intéressement } \\
\cline { 2 - 7 } Household Type & 0,99 & 223,64 & 103,70 & 0,86 & 221,88 & 103,70 \\
\cline { 2 - 7 } \% positive gains & Mean & Median & \% positive gains & Mean & Median \\
Single female, no children & 0,97 & 224,20 & 103,70 & 0,85 & 222,33 & 103,70 \\
Single female, 1 child & 0,99 & 148,93 & 103,70 & 0,72 & 145,69 & 103,70 \\
Single female, 2 children & 0,97 & 168,64 & 103,70 & 0,78 & 165,93 & 103,70 \\
Single female, $>$ 2 children & 1,00 & 251,35 & 193,56 & 0,88 & 249,73 & 193,56 \\
Single male, no children & 0,99 & 281,30 & 103,70 & 0,95 & 280,74 & 103,70 \\
Single male, with children & 1,00 & 232,59 & 103,70 & 0,94 & 231,70 & 103,70 \\
Couple, no children & 0,99 & 178,30 & 103,70 & 0,86 & 176,65 & 103,70 \\
Couple, 1 child & 0,99 & 183,23 & 103,70 & 0,80 & 180,52 & 103,70 \\
Couple, 2 children & 0,98 & 170,23 & 103,70 & 0,80 & 167,37 & 103,70 \\
Couple, $>$ 2 children & 0,99 & 228,42 & 119,20 & 0,86 & 226,37 & 118,87 \\
& & & & & & \\
\end{tabular}

Monthly gains per adult equivalent

\begin{tabular}{lcccccc} 
& \multicolumn{6}{c}{ Monthly gains per adult equivalent } \\
\cline { 2 - 7 } & \multicolumn{3}{c}{ Baseline simulation } & \multicolumn{3}{c}{ Without Intéressement } \\
\cline { 2 - 7 } Household Type & \% positive gains & Mean & Median & \% positive gains & Mean & Median \\
\hline All beneficiaries & 0,99 & 174,62 & 103,70 & 0,86 & 173,48 & 103,70 \\
Single female, no children & 0,97 & 224,20 & 103,70 & 0,85 & 222,33 & 103,70 \\
Single female, 1 child & 0,99 & 99,29 & 69,13 & 0,72 & 97,13 & 69,13 \\
Single female, 2 children & 0,97 & 84,32 & 51,85 & 0,78 & 82,97 & 51,85 \\
Single female, > 2 children & 1,00 & 93,90 & 71,19 & 0,88 & 93,28 & 71,19 \\
Single male, no children & 0,99 & 281,30 & 103,70 & 0,95 & 280,74 & 103,70 \\
Single male, with children & 1,00 & 139,38 & 69,13 & 0,94 & 138,80 & 69,13 \\
Couple, no children & 0,99 & 104,88 & 61,00 & 0,86 & 103,91 & 61,00 \\
Couple, 1 child & 0,99 & 83,29 & 47,14 & 0,80 & 82,06 & 47,14 \\
Couple, 2 children & 0,98 & 63,05 & 38,41 & 0,80 & 61,99 & 38,41 \\
Couple, $>$ 2 children & 0,99 & 65,22 & 32,46 & 0,86 & 64,61 & 32,45
\end{tabular}

\begin{tabular}{lcccccc}
\hline & \multicolumn{3}{c}{ Monthly gains increase as a percentage of non-employment income } \\
\cline { 2 - 7 } & \multicolumn{3}{c}{ Baseline simulation } & \multicolumn{3}{c}{ Without Intéressement } \\
\cline { 2 - 7 } Household Type & 0,99 & 0,46 & 0,21 & 0,86 & 0,46 & 0,21 \\
\cline { 2 - 7 } \% positive gains & Mean & Median & \% positive gains & Mean & Median \\
Single female, no children & 0,97 & 0,57 & 0,32 & 0,85 & 0,56 & 0,32 \\
Single female, 1 child & 0,99 & 0,23 & 0,14 & 0,72 & 0,23 & 0,14 \\
Single female, 2 children & 0,97 & 0,21 & 0,12 & 0,78 & 0,21 & 0,12 \\
Single female, $>$ 2 children & 1,00 & 0,25 & 0,19 & 0,88 & 0,25 & 0,19 \\
Single male, no children & 0,99 & 0,75 & 0,32 & 0,95 & 0,74 & 0,32 \\
Single male, with children & 1,00 & 0,31 & 0,14 & 0,94 & 0,31 & 0,14 \\
Couple, no children & 0,99 & 0,28 & 0,15 & 0,86 & 0,28 & 0,15 \\
Couple, 1 child & 0,99 & 0,25 & 0,13 & 0,80 & 0,24 & 0,13 \\
Couple, 2 children & 0,98 & 0,19 & 0,11 & 0,80 & 0,19 & 0,11 \\
Couple, $>$ 2 children & 0,99 & 0,20 & 0,11 & 0,86 & 0,20 & 0,11
\end{tabular}

Source: Authors' calculations based on the Devenir des personnes sorties du RMI survey. Gains are based on estimated wages and hours potentially offered by employers. They are measured in Euros, and are computed as monthly flow from intertemporal wealth. The equivalence scale uses weights: 1 for first adult, 0.7 for second adult and 0.5 for children. 


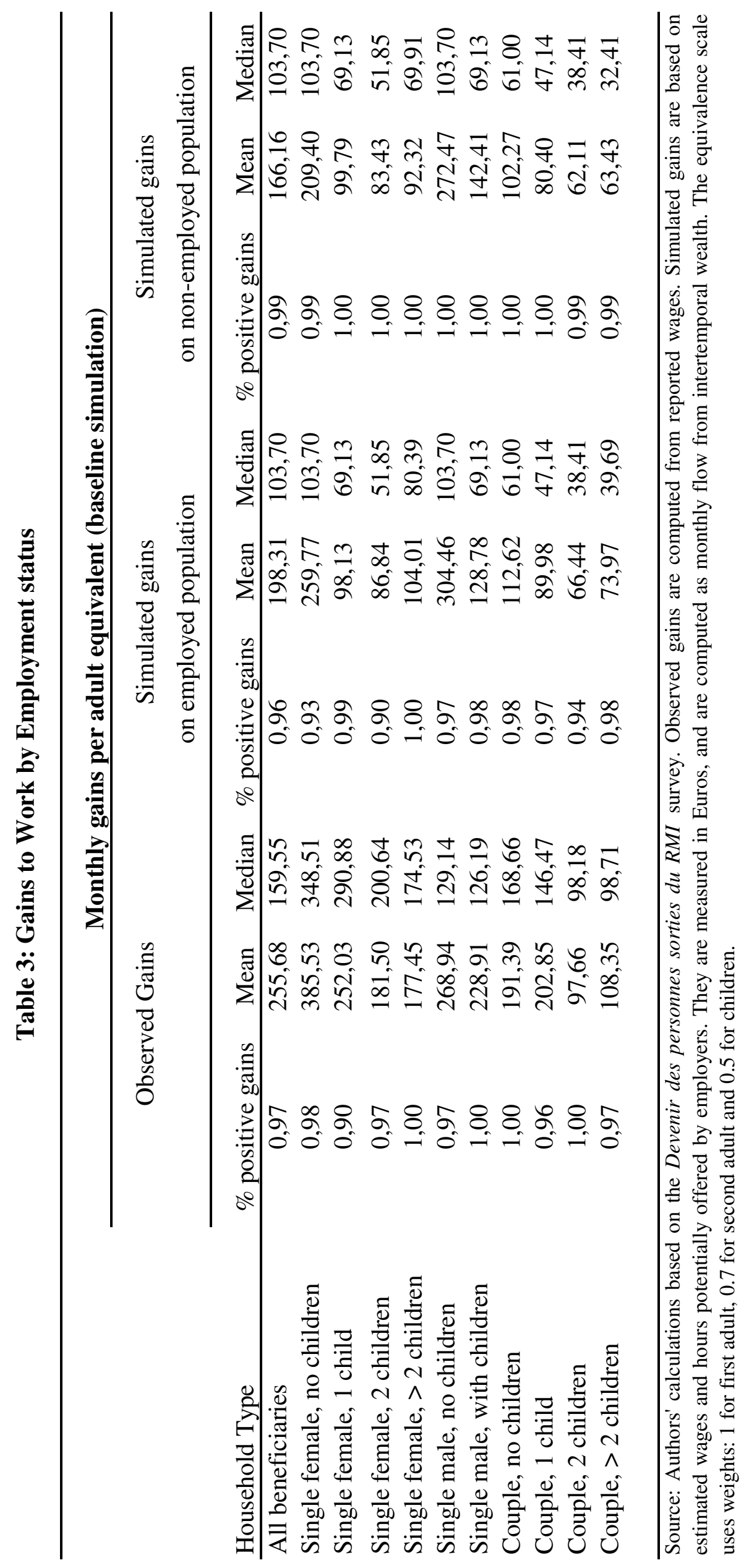


Table 4: Results of the Structural Employment Model (single persons)

\begin{tabular}{|c|c|c|c|c|}
\hline & \multicolumn{4}{|c|}{ Men } \\
\hline & $(1)$ & $(2)$ & $(3)$ & $(4)$ \\
\hline \multirow[t]{2}{*}{ Intercept } & $-1,1853$ & $-1,9807$ & $-1,1348$ & $-1,5262$ \\
\hline & $(0,0952)$ & $(0,7038)$ & $(0,0947)$ & $(0,6849)$ \\
\hline \multirow[t]{2}{*}{ Log disposable income } & 0,9672 & 0,7974 & 0,3369 & 1,1208 \\
\hline & $(0,1619)$ & $(0,2169)$ & $(0,2381)$ & $(0,2155)$ \\
\hline Direct effect of hours: & & 0,1877 & & 0,0737 \\
\hline Log hours worked & & $(0,1643)$ & & $(0,1604)$ \\
\hline Direct effect of hours: & & \\
\hline \multicolumn{2}{|l|}{ Full time dummy (>130 monthly hours) } & \multicolumn{3}{|c|}{$(0,1931)$} \\
\hline \multirow[t]{2}{*}{ Age } & $-0,3886$ & $-0,3963$ & \multirow{2}{*}{\multicolumn{2}{|c|}{$\begin{array}{c}-0,411 \\
(0,0599)\end{array}$}} \\
\hline & $(0,0580)$ & $(0,0585)$ & & \\
\hline \multicolumn{5}{|l|}{$\begin{array}{l}\text { Joint significance of disposable income } \\
\text { and hours variable (Wald test) }\end{array}$} \\
\hline Implied elasticity w.r.t. disposable income & 1,17 & 0,96 & 0,39 & 1,25 \\
\hline Implied elasticity w.r.t. gross earnings & 0,53 & 0,43 & 0,16 & 0,59 \\
\hline Number of Observations & 820 & 820 & 820 & 820 \\
\hline \multirow[t]{3}{*}{ Log Likelihood } & $-424,25$ & $-423,55$ & $-418,55$ & $-448,18$ \\
\hline & \multicolumn{4}{|c|}{ Women } \\
\hline & $(1)$ & $(2)$ & $(3)$ & $(4)$ \\
\hline \multirow[t]{2}{*}{ Intercept } & $-0,9537$ & $-2,4075$ & $-0,9245$ & $-2,1995$ \\
\hline & $(0,0782)$ & $(0,5088)$ & $(0,0783)$ & $(0,4975)$ \\
\hline \multirow[t]{2}{*}{ Log disposable income } & 0,8903 & 0,4386 & 0,3647 & 0,7331 \\
\hline & $(0,2160)$ & $(0,2629)$ & $(0,2967)$ & $(0,2534)$ \\
\hline \multicolumn{2}{|l|}{ Direct effect of hours: } & 0,3499 & & 0,2895 \\
\hline \multicolumn{2}{|l|}{ Log hours worked } & $(0,1206)$ & & $(0,1176)$ \\
\hline \multicolumn{2}{|l|}{ Direct effect of hours: } & \multicolumn{3}{|c|}{0,4854} \\
\hline \multicolumn{2}{|l|}{ Full time dummy (>130 monthly hours) } & \multicolumn{3}{|c|}{$(0,1999)$} \\
\hline \multirow[t]{2}{*}{ Age } & $-0,2817$ & $-0,2972$ & \multirow{2}{*}{\multicolumn{2}{|c|}{$\begin{array}{l}-0,2712 \\
(0,0545)\end{array}$}} \\
\hline & $(0,0520)$ & $(0,0523)$ & & \\
\hline \multirow[t]{2}{*}{ Number of Children: 0-2 Years Old } & $-0,4396$ & $-0,4528$ & $-0,4527$ & $-0,4147$ \\
\hline & $(0,1084)$ & $(0,1104)$ & $(0,1109)$ & $(0,1101)$ \\
\hline \multirow[t]{2}{*}{ Number of Children: 3-14 Years Old } & 0,0237 & 0,0011 & $-0,0075$ & 0,0548 \\
\hline & $(0,0577)$ & $(0,0731)$ & $(0,0784)$ & $(0,0582)$ \\
\hline \multirow[t]{2}{*}{ Number of Children: $15+$ Years Old } & 0,031 & 0,0173 & 0,0212 & $-0,0693$ \\
\hline & $(0,0486)$ & $(0,0548)$ & $(0,0559)$ & $(0,0476)$ \\
\hline \multicolumn{4}{|l|}{ Joint significance of disposable income } & 33,94 \\
\hline Implied elasticity w.r.t. disposable income & 1,10 & 0,54 & 0,44 & 0,86 \\
\hline Implied elasticity w.r.t. gross earnings & 0,36 & 0,17 & 0,14 & 0,31 \\
\hline Number of Observations & 952 & 952 & 952 & 952 \\
\hline Log Likelihood & $-514,44$ & $-509,82$ & $-511,36$ & $-526,38$ \\
\hline
\end{tabular}


Table 5: Policy impacts on labour supply

\begin{tabular}{|c|c|c|}
\hline & Men & Women \\
\hline & \multicolumn{2}{|c|}{ Baseline } \\
\hline Observed employment rate & $27,44 \%$ & $27,42 \%$ \\
\hline Simulated employment rate & $27,21 \%$ & $27,48 \%$ \\
\hline \multirow[t]{2}{*}{ Monthly value of net transfers } & 325 & 521 \\
\hline & \multicolumn{2}{|c|}{ No intéressement } \\
\hline In-work disp inc. Increase & $-0,09 \%$ & $-0,31 \%$ \\
\hline Simulated employment rate & $27,18 \%$ & $27,43 \%$ \\
\hline \multirow[t]{2}{*}{ Monthly value of net transfers } & 325 & 521 \\
\hline & \multicolumn{2}{|c|}{ Full intéressement } \\
\hline In-work disp inc. Increase & $1,50 \%$ & $5,80 \%$ \\
\hline Simulated employment rate & $27,63 \%$ & $28,37 \%$ \\
\hline \multirow[t]{2}{*}{ Monthly value of net transfers } & 326 & 531 \\
\hline & \multicolumn{2}{|c|}{ Prime pour l'emploi } \\
\hline In-work disp inc. Increase & $10,38 \%$ & $8,37 \%$ \\
\hline Simulated employment rate & $29,59 \%$ & $28,56 \%$ \\
\hline \multirow[t]{2}{*}{ Monthly value of net transfers } & 341 & 539 \\
\hline & \multicolumn{2}{|c|}{ Minimum wage increase $(+10 \%)$} \\
\hline In-work disp inc. Increase & $7,35 \%$ & $4,57 \%$ \\
\hline Simulated employment rate & $28,86 \%$ & $28,06 \%$ \\
\hline Monthly value of net transfers & 318 & 516 \\
\hline
\end{tabular}

Source: Authors' estimates using the Devenir des personnes sorties du RMI survey limited to single persons. Results based on estimates presented in Table 4, col. (2). All values are averages over the distribution of potential hours/wages (except "observed employment rate") and over persons. 
Appendix table 1 : Descriptive Statistics, full sample

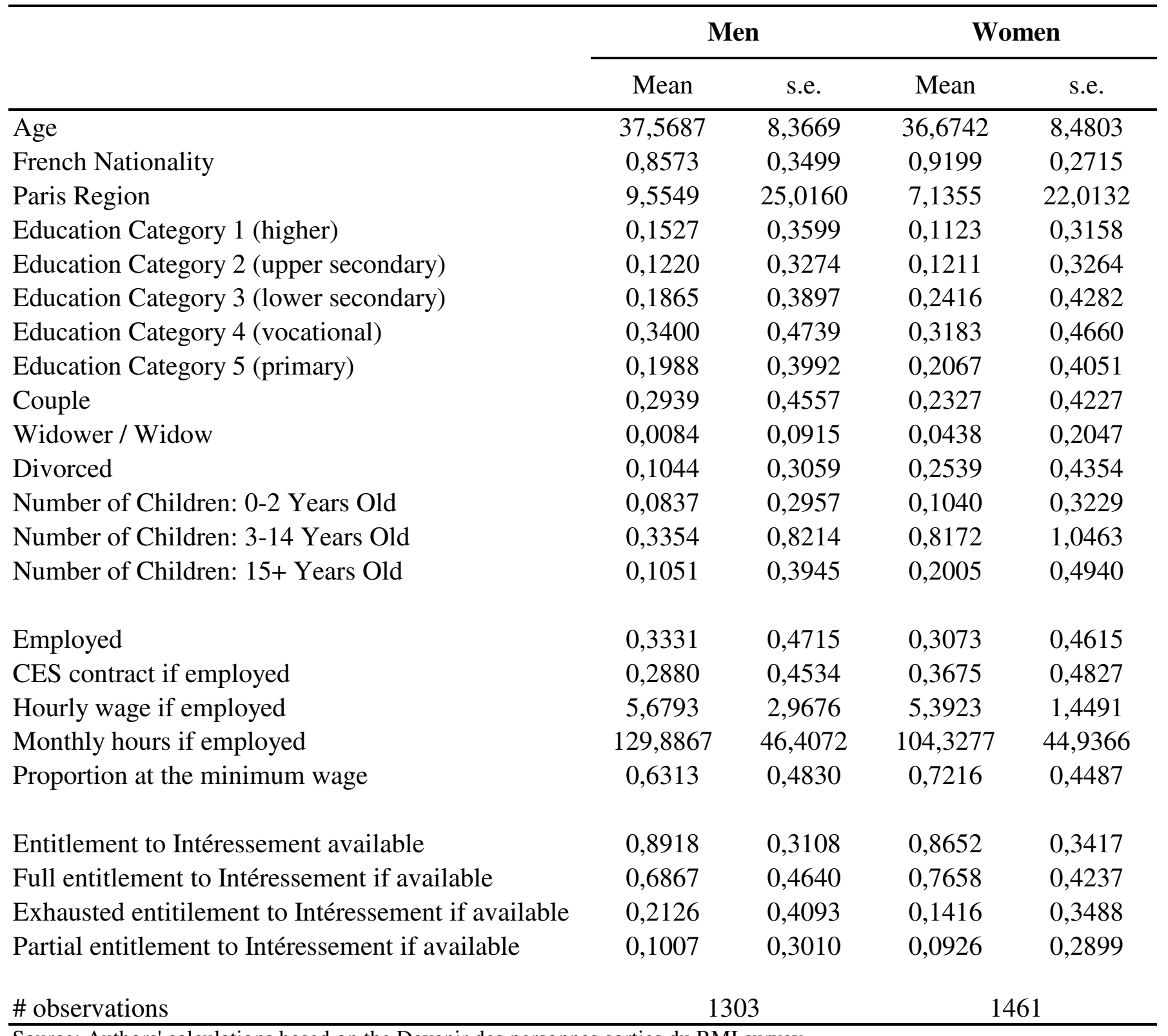

Source: Authors' calculations based on the Devenir des personnes sorties du RMI survey. 
Appendix table 2 : Descriptive Statistics, single persons

\begin{tabular}{|c|c|c|c|c|}
\hline & \multicolumn{2}{|c|}{ Men } & \multicolumn{2}{|c|}{ Women } \\
\hline & Mean & s.e. & Mean & s.e. \\
\hline Age & 37,0793 & 8,2706 & 37,2857 & 8,4807 \\
\hline French Nationality & 0,8902 & 0,3128 & 0,9275 & 0,2594 \\
\hline Paris Region & 11,4329 & 26,9749 & 8,1145 & 23,3091 \\
\hline Education Category 1 (higher) & 0,1756 & 0,3807 & 0,1271 & 0,3333 \\
\hline Education Category 2 (upper secondary) & 0,1427 & 0,3500 & 0,1197 & 0,3248 \\
\hline Education Category 3 (lower secondary) & 0,1890 & 0,3918 & 0,2227 & 0,4163 \\
\hline Education Category 4 (vocational) & 0,3244 & 0,4684 & 0,3151 & 0,4648 \\
\hline Education Category 5 (primary) & 0,1683 & 0,3744 & 0,2153 & 0,4113 \\
\hline Widower / Widow & 0,0073 & 0,0853 & 0,0620 & 0,2412 \\
\hline Divorced & 0,1561 & 0,3632 & 0,3288 & 0,4700 \\
\hline Number of Children: 0-2 Years Old & 0,0012 & 0,0349 & 0,0546 & 0,2319 \\
\hline Number of Children: 3-14 Years Old & 0,0280 & 0,2220 & 0,6271 & 0,8813 \\
\hline Number of Children: 15+ Years Old & 0,0146 & 0,1390 & 0,2059 & 0,5020 \\
\hline Employed & 0,2744 & 0,4465 & 0,2742 & 0,4463 \\
\hline CES contract if employed & 0,2089 & 0,4074 & 0,2797 & 0,4497 \\
\hline Hourly wage if employed & 6,0533 & 3,8597 & 5,4869 & 1,6563 \\
\hline Monthly hours if employed & 137,4143 & 46,0791 & 115,5030 & 45,3367 \\
\hline Proportion at the minimum wage & 0,5467 & 0,4989 & 0,6973 & 0,4603 \\
\hline Full entitlement to Intéressement if available & 0,7012 & 0,4580 & 0,7290 & 0,4447 \\
\hline Exhausted entitilement to Intéressement if available & 0,1951 & 0,3965 & 0,1628 & 0,3694 \\
\hline Partial entitlement to Intéressement if available & 0,1037 & 0,3050 & 0,1082 & 0,3108 \\
\hline \# observations & \multicolumn{2}{|c|}{820} & \multicolumn{2}{|c|}{952} \\
\hline
\end{tabular}

Source: Authors' calculations based on the Devenir des personnes sorties du RMI survey. The sample is restricted to single persons for which entitlement to Intéressement is known. 


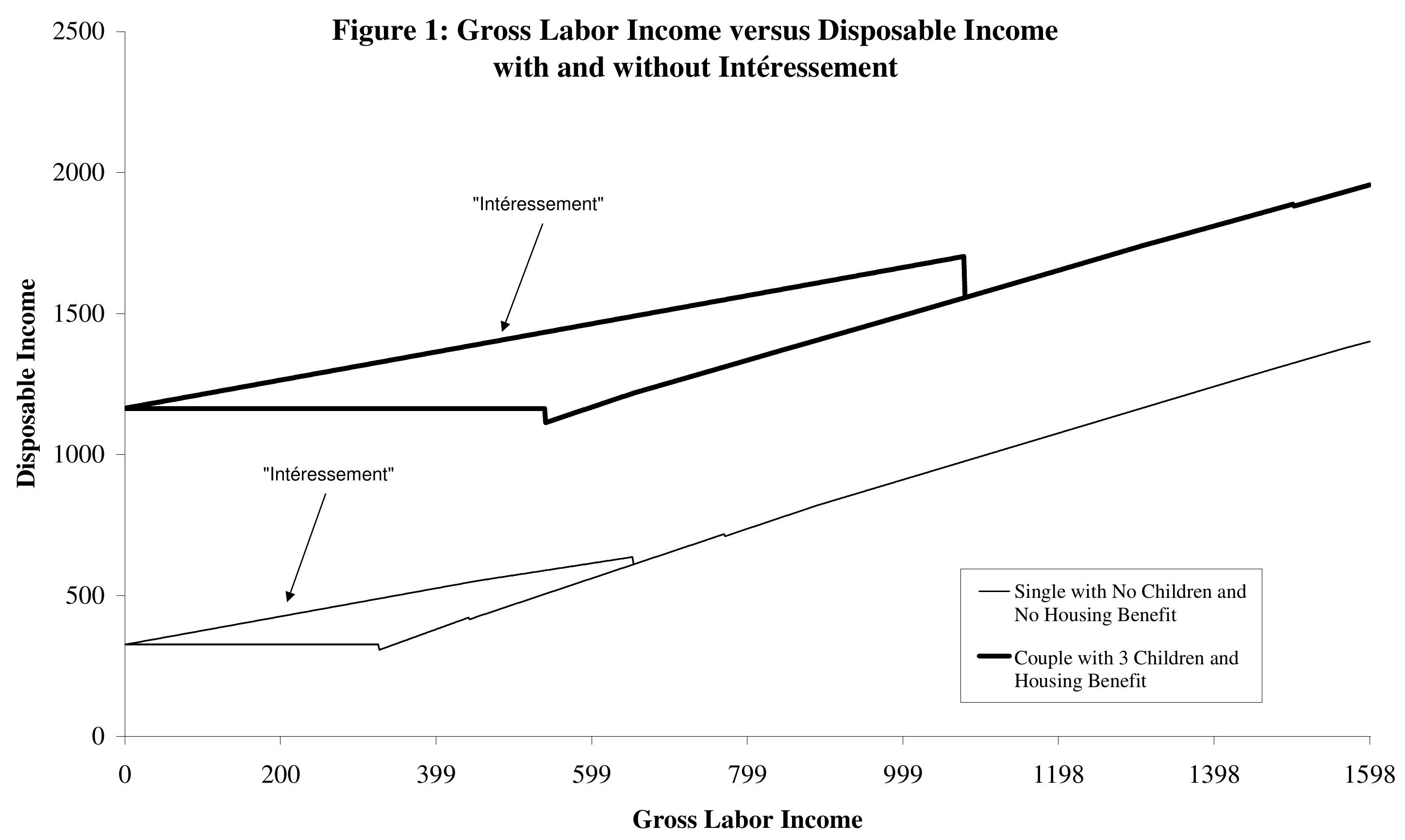




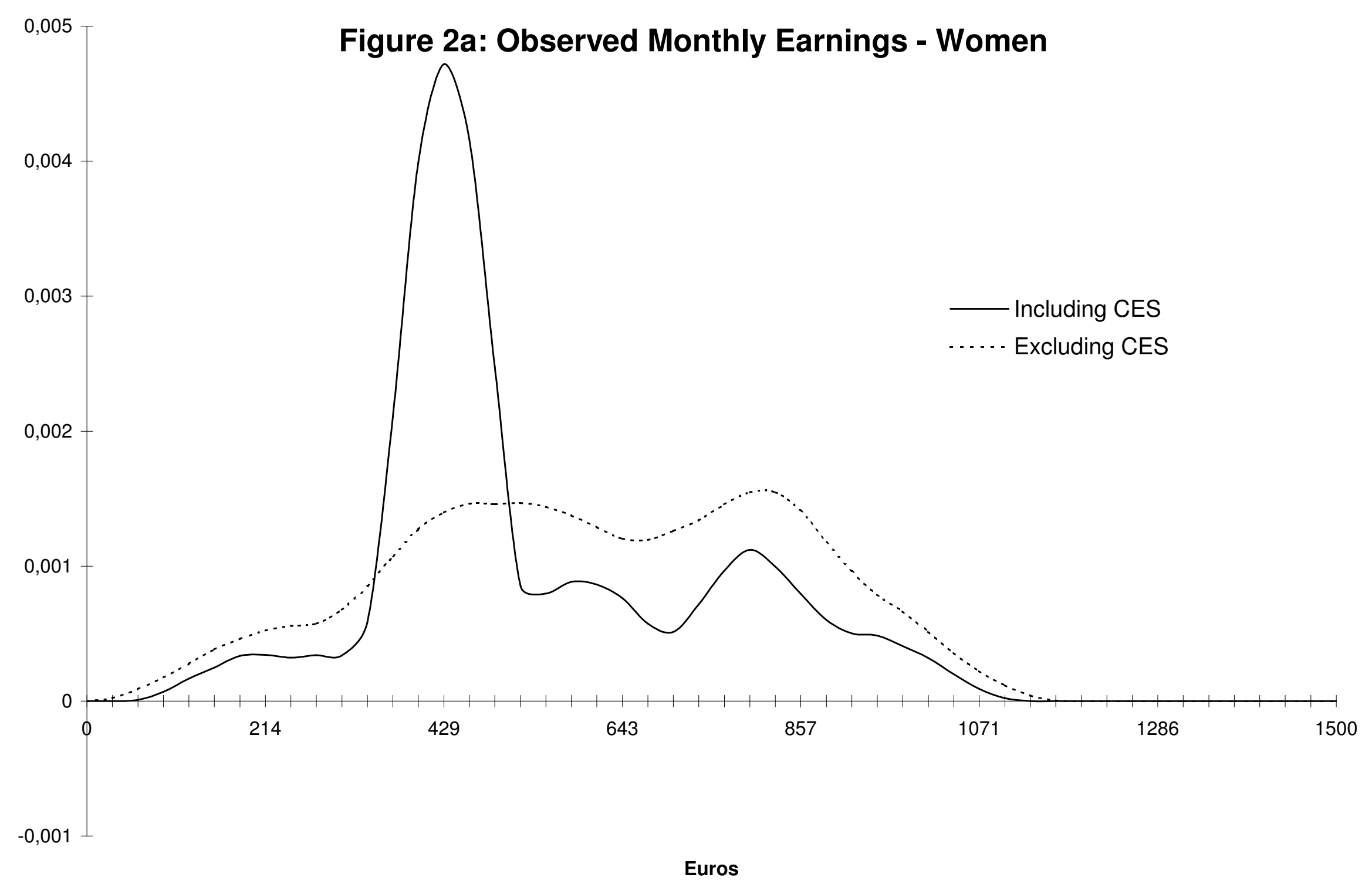




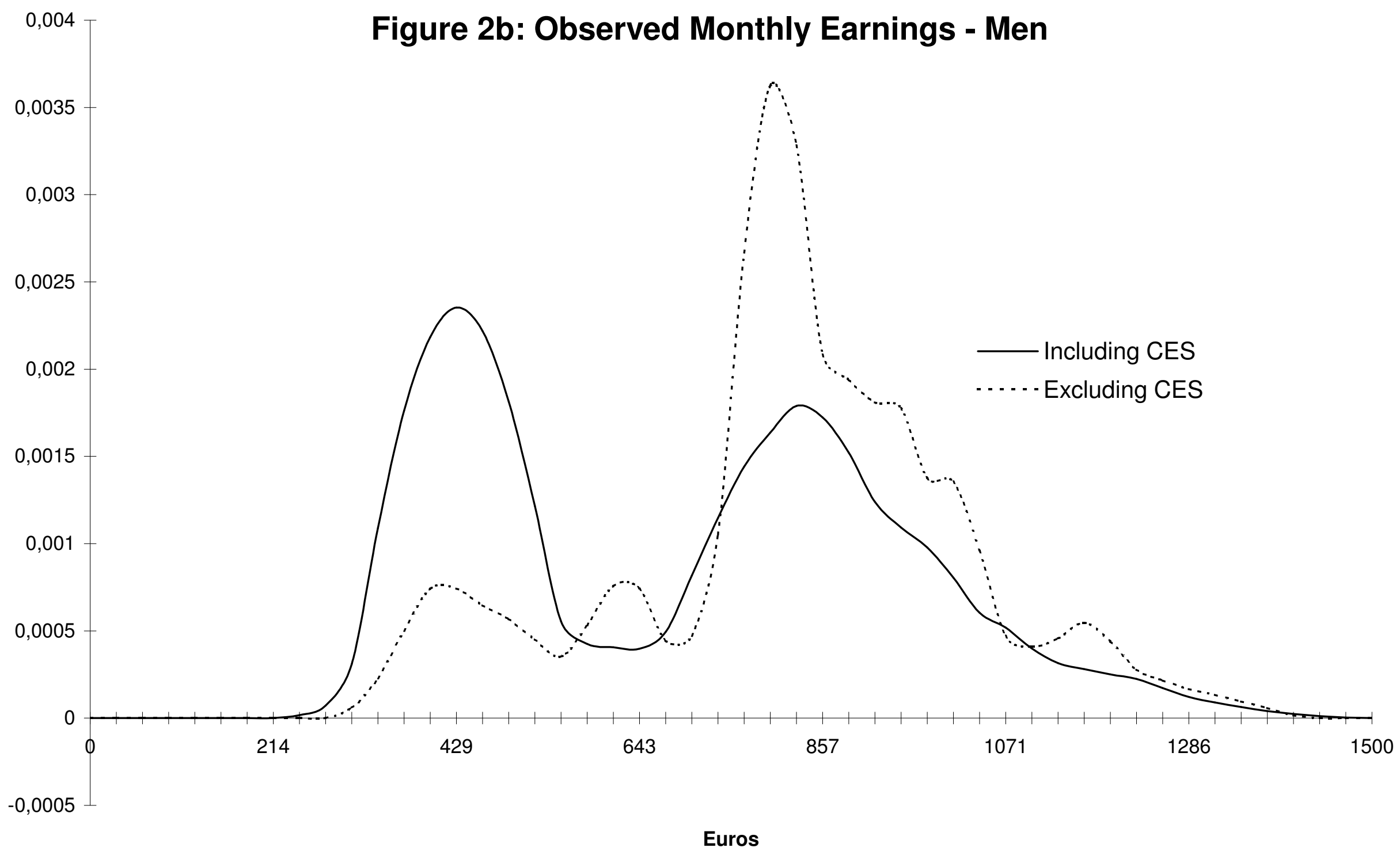




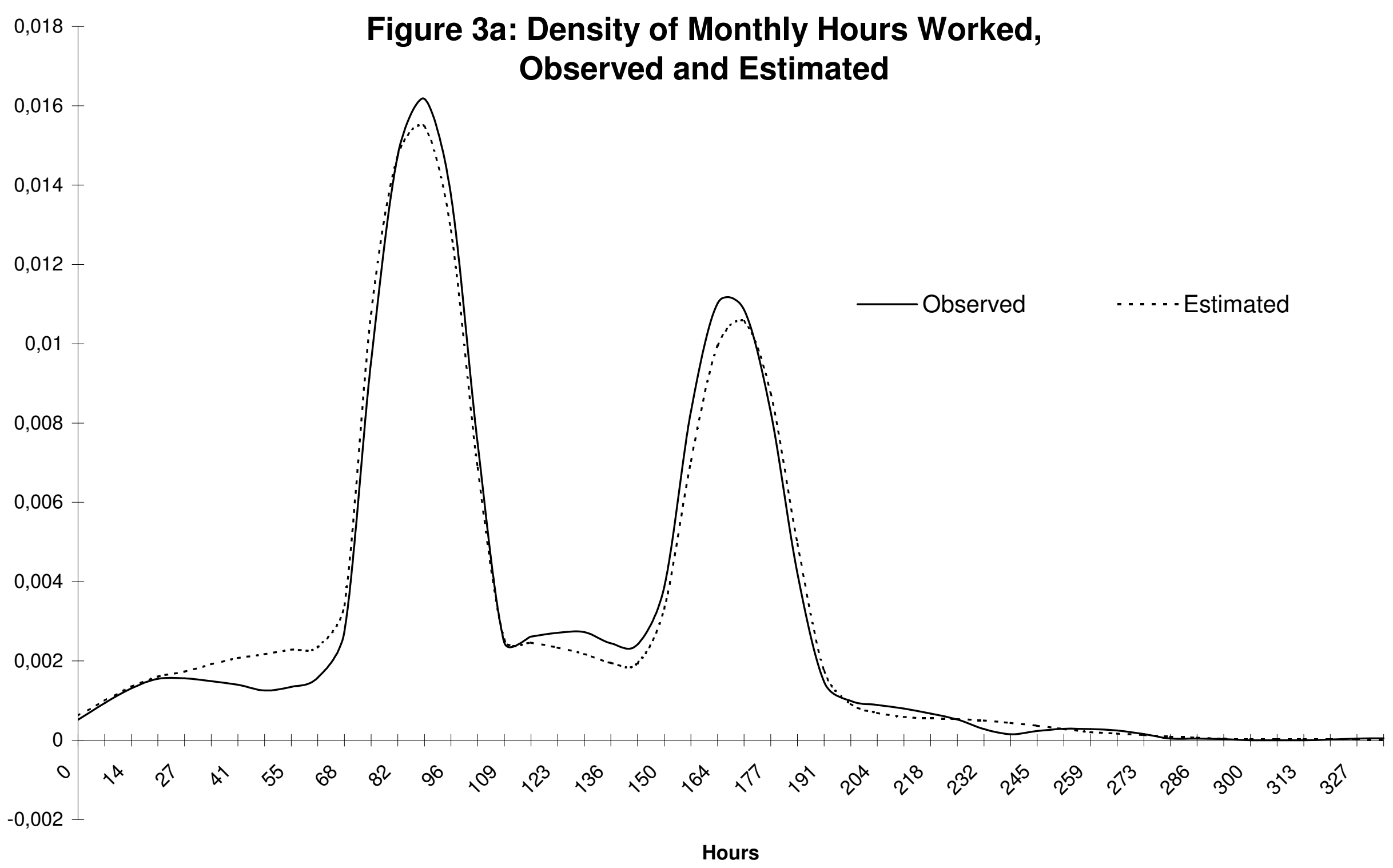




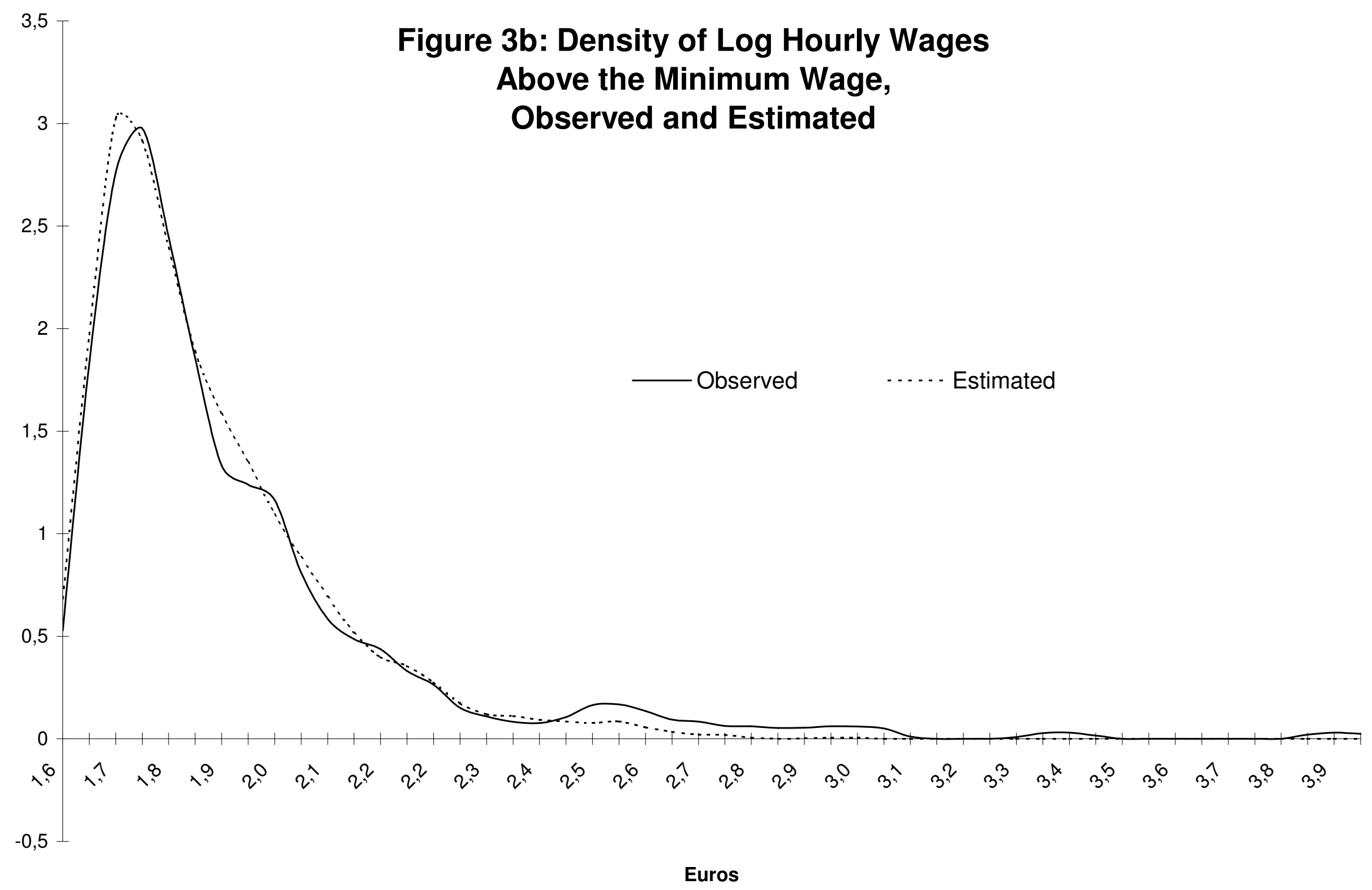




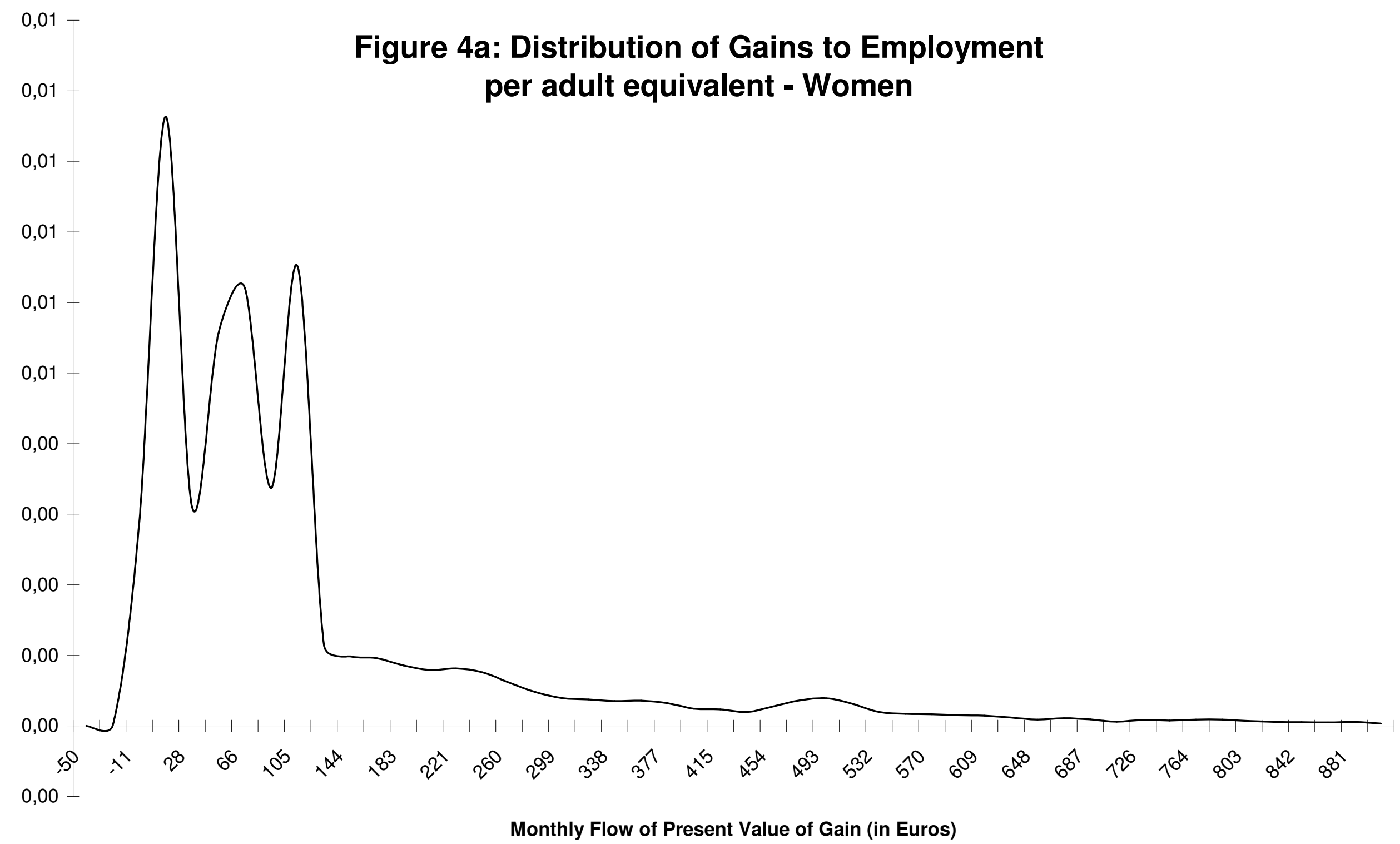




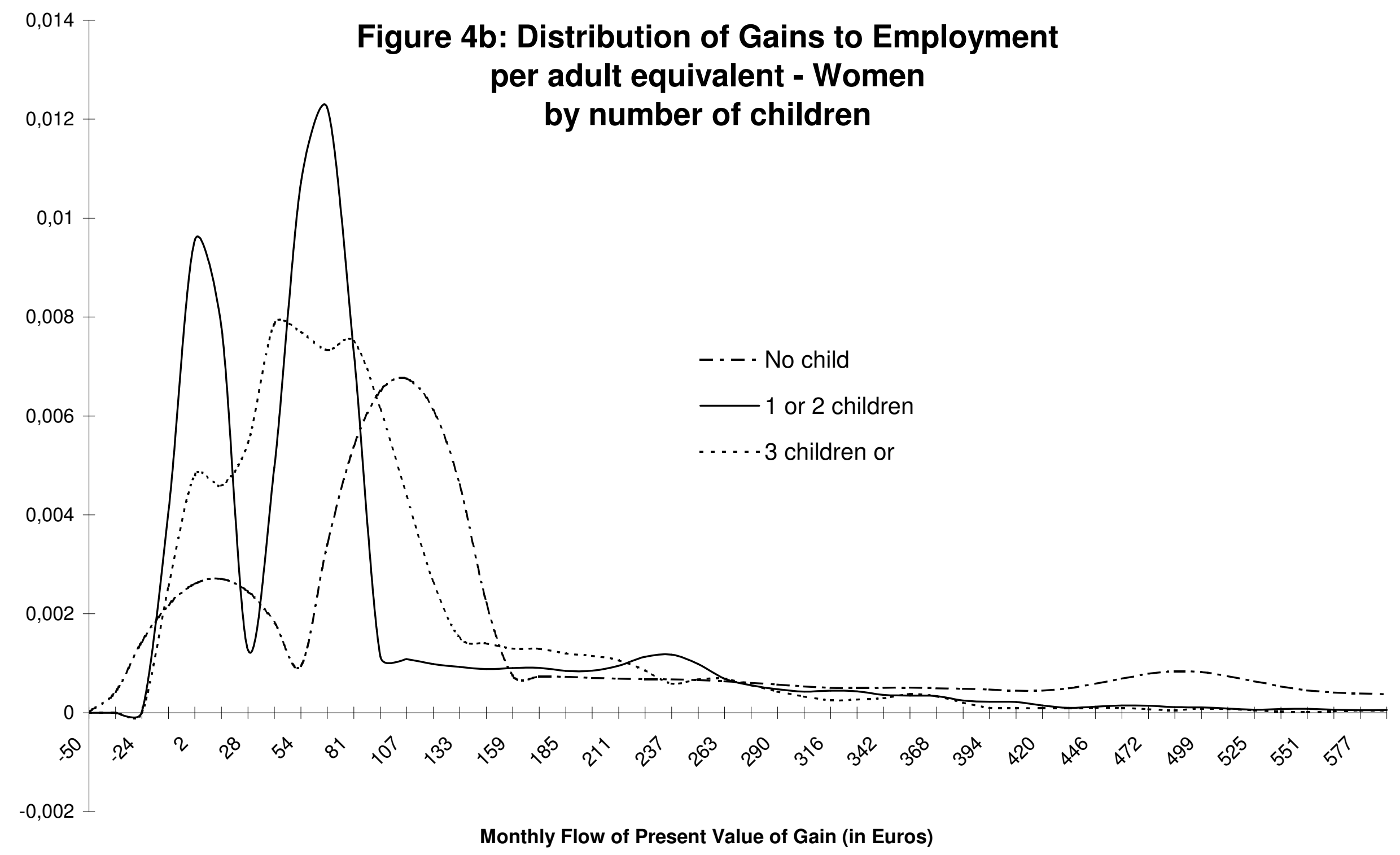




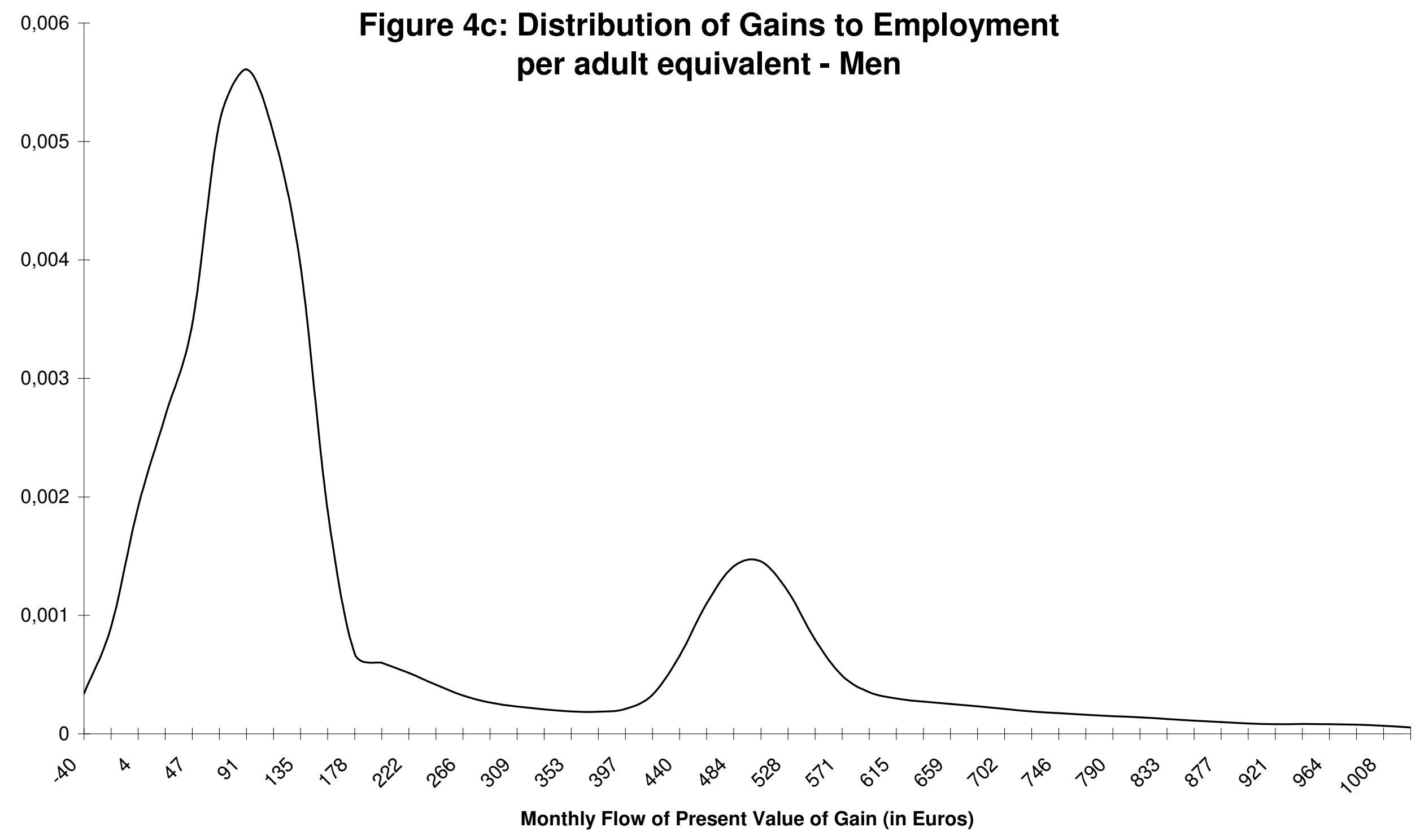




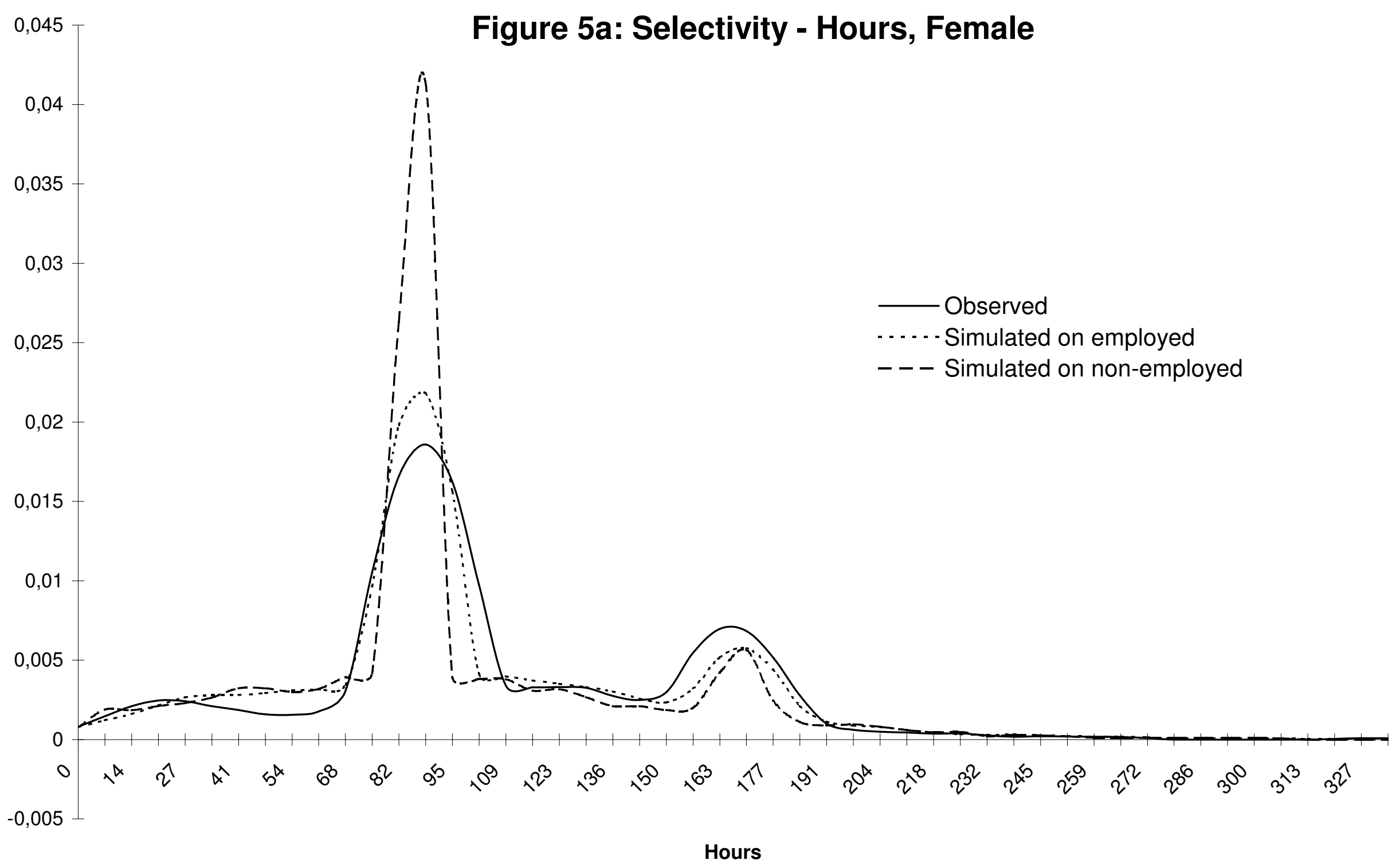




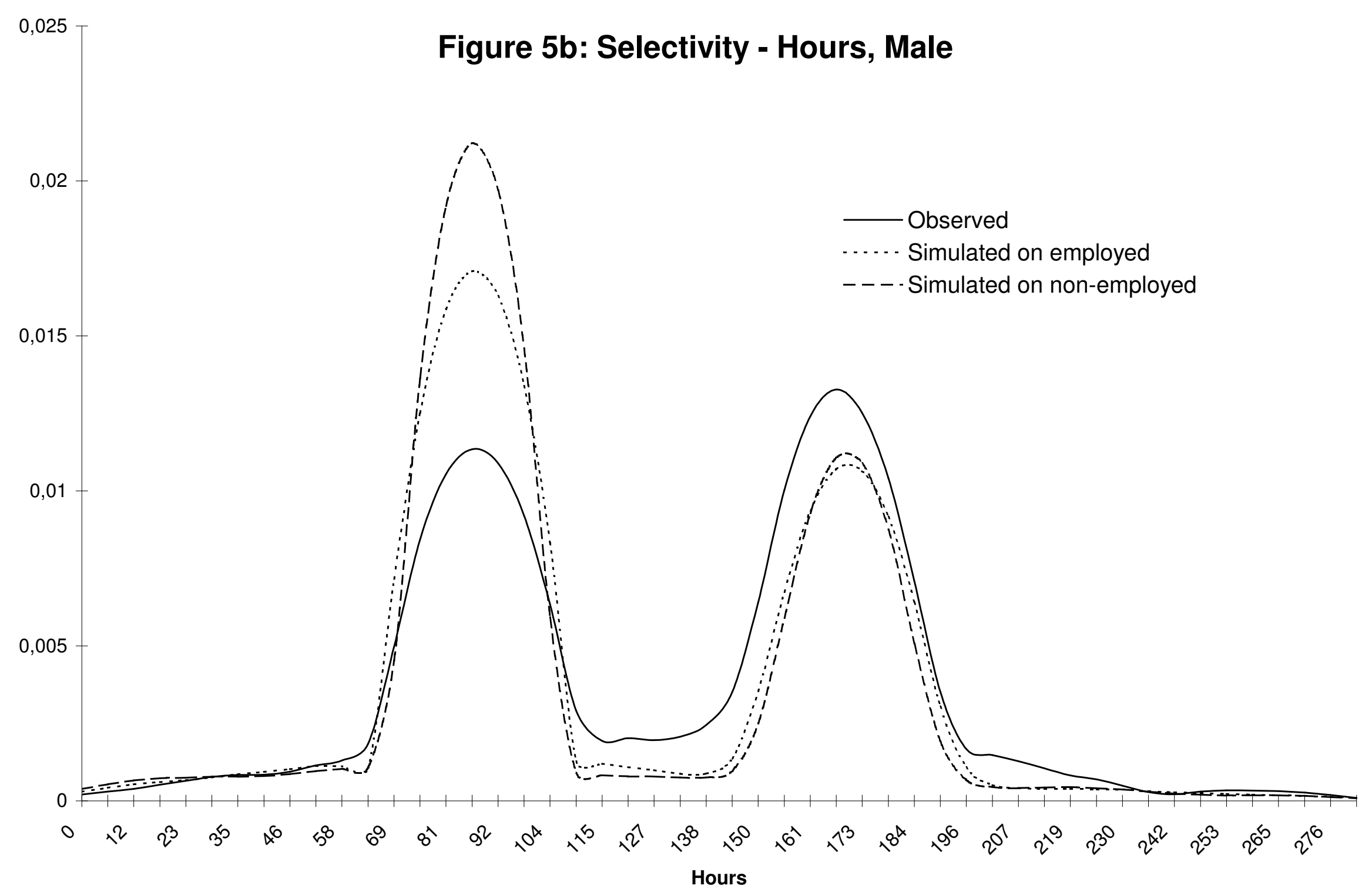

